\title{
Phylogenetics of Acrocirridae and Flabelligeridae (Cirratuliformia, Annelida)
}

\author{
Karen J. Osborn \& Greg W. Rouse
}

Submitted: 26 July 2010

Accepted: 5 October 2010

doi:10.1111/j.1463-6409.2010.00460.x

\begin{abstract}
Osborn, K. J. \& Rouse, G. W. (2010). Phylogenetics of Acrocirridae and Flabelligeridae (Cirratuliformia, Annelida). - Zoologica Scripta, 40, 204-219.

When seven deep-sea, swimming cirratuliforms were recently discovered, the need for a thorough phylogenetic hypothesis for Cirratuliformia was clear. Here, we provide a robust phylogenetic hypothesis for the relationships within Acrocirridae and increase the taxon sampling and resolution within Flabelligeridae based on both molecular (18S, 28S, $16 S$, $C O I$ and $C y t B$ ) and morphological data. Data partitions were analyzed separately and in combination. Acrocirridae and Flabelligeridae were reciprocally monophyletic sister groups when rooted by cirratulids. The seven recently discovered species form a clade within Acrocirridae and will be designated as four genera based on phylogenetic relationships and apomorphies. A revised diagnosis is provided for Swima, restricting the genus to three species distinguished by a thick gelatinous sheath, transparent body, simple nuchal organs, a single medial subulate branchia, and four pair of small segmental branchiae modified as elliptical, bioluminescent sacs. Helmetophorus and Chauvinelia are maintained as separate genera based on morphological differences. Evidence for flabelligerid branchiae being segmental is provided, the papillae on segment two of most acrocirrids is confirmed to be the nephridiopores, and scanning electron microscopy is used to examine acrocirrid spinous chaetae in comparison with flabelligerid segmented chaetae.

Corresponding author: Karen 7. Osborn, Institute of Marine Science, University of California, Santa Cruz, Earth \& Marine Sciences Building, 1156 High Street, Santa Cruz, CA 95064, USA.E-mail: kosborn@ucsc.edu

Greg W. Rouse, Scripps Institution of Oceanography, University of California, San Diego, La folla, CA 92093-0202, USA. E-mail: grouse@ucsd.edu
\end{abstract}

\section{Introduction}

The recent discovery of seven new members of Acrocirridae (Fig. 1; Table 1; Osborn et al. 2009) emphasized the need for a thorough phylogenetic treatment of Cirratuliformia. Addition of these new species to Acrocirridae, one of which, Swima bombiviridis, was formally described in Osborn et al. (2009), markedly increased the morphological and size diversity within the group. The striking differences observed between the recently discovered swimming species and other known acrocirrids were not surprising considering the pelagic (living in open water, not associated with the seafloor) and benthopelagic (living both in the water column and associated with the seafloor) lifestyles of the new species. Interestingly, some acrocirrids Helmetophorus rankini Hartman 1978; Chauvinelia spp. and possibly even some Acrocirrus were previously suspected of being able to swim (Banse 1969; Averincev 1980; Kirkegaard 1982). Also, several flabelligerids are pelagic, Buskiella abyssorum McIntosh 1885 (Mesnil 1899; Fauvel 1916), Flota spp. and Poeobius meseres Heath 1930, and these likewise differ dramatically from their benthic relatives. These swimming flabelligerids and acrocirrids possess features, e.g. thick gelatinous sheathes and long, clavate papillae, numerous elongate chaetae ( $P$. meseres excepted), broad, flat chaetae (two of the recently discovered species), transparent bodies, and bioluminescence that may be homologous or convergent. Yet to understand the origin of the unusual structures found in the various swimming species and to understand the evolutionary transformations that took place in the transition from benthic to pelagic, a well-resolved evolutionary history of Cirratuliformia is needed.

Rouse \& Fauchald (1997) found Acrocirridae, Cirratulidae, Ctenodrilidae, Fauveliopsidae, Flabelligeridae, Flotidae, Poeobiidae and Sternaspidae formed a clade later named Cirratuliformia (Rouse \& Pleijel 2001). Poeobiidae 

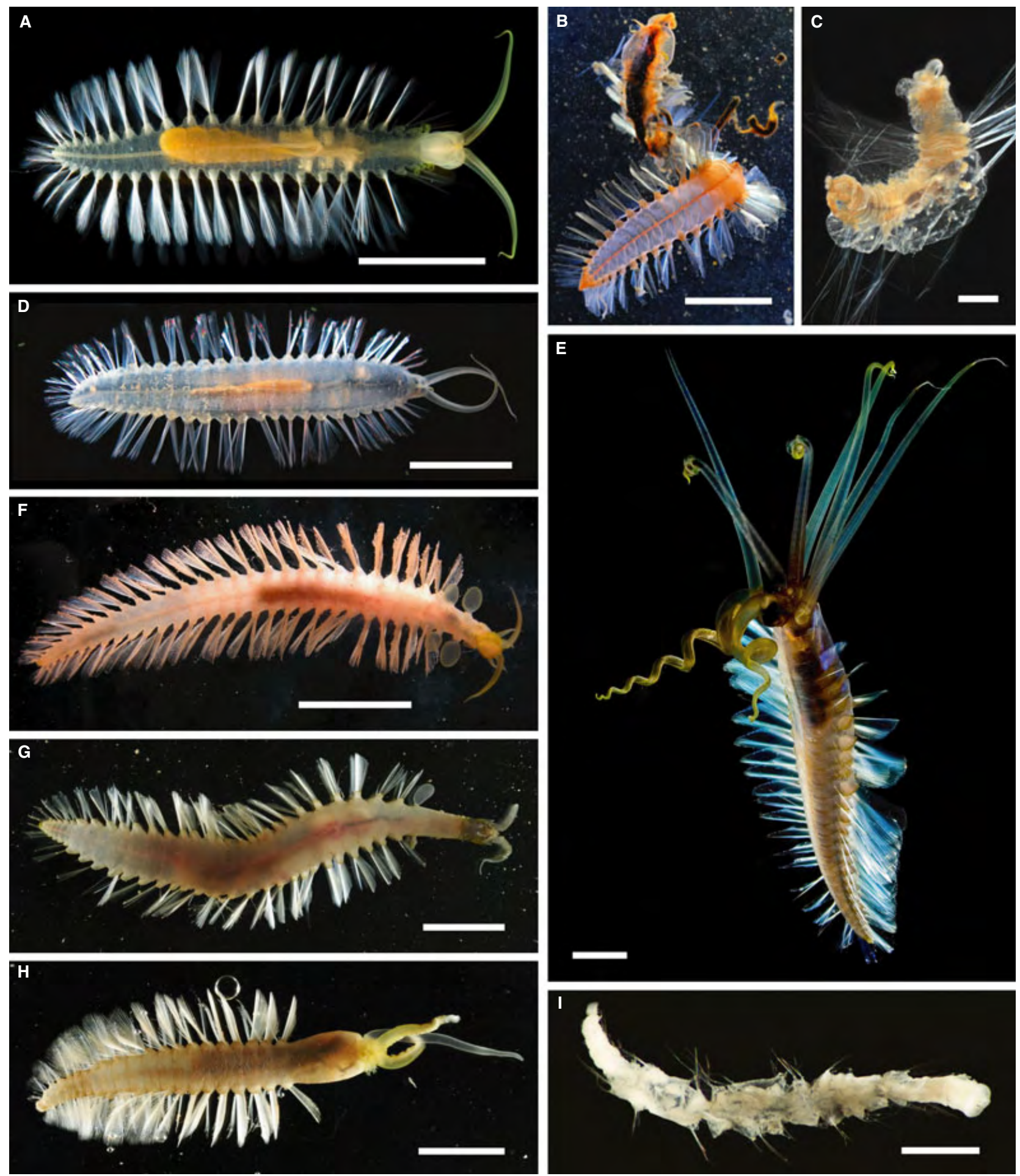

Fig. 1 Swimming acrocirrids. -A. Swima bombiviridis, photo C. W. Dunn. -B. 'Tawi-tawi Bomber', photo L. P. Madin. —C. Chauvinelia arctica ZMUC POL-0159. -D. 'Shining Bomber' missing all elliptical branchiae. —E. 'Squidworm' missing a branchia, photo M. Aw. -F. 'Horned Bomber' missing three elliptical branchiae. —G. 'Tiburon Bomber' missing six elliptical branchiae, photo F. Pleijel. - H. 'Juanita worm' missing seven branchiae, photo F. Pleijel. -I. Helmetophorus rankini type USNM-46749. Scale bars: A-B and $\mathrm{D}-\mathrm{H}=10 \mathrm{~mm}, \mathrm{C}$ and $\mathrm{I}=1 \mathrm{~mm}$. 


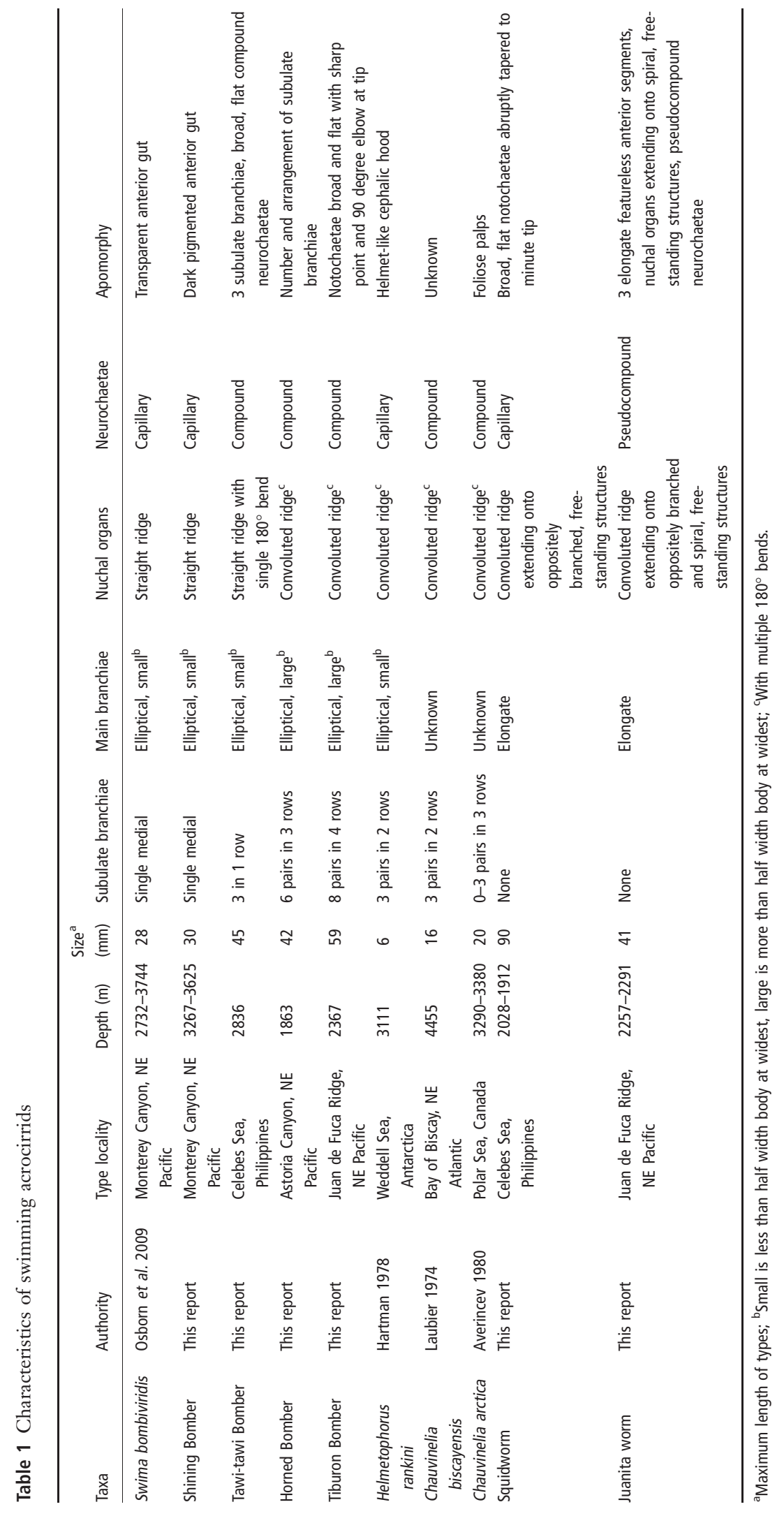


and Flotidae were recently synonymized with Flabelligeridae (Poeobius by Burnette et al. 2005; Flota by Osborn \& Rouse 2008) and Ctenodrilidae placed within Cirratulidae (Bleidorn et al. 2003a; Rouse \& Pleijel 2003). The question of the affinities of Sternaspidae and Fauveliopsidae remain unresolved, but Struck et al. (2007) and Rousset et al. (2007) both found these taxa to be sistergroups and not closely related to other Cirratuliformia. Thus, Cirratuliformia could be considered to consist of three families, Cirratulidae, Acrocirridae and Flabelligeridae. These three families share several distinctive features including: a pair of large anterior nephridia, chlorocruorin as a blood pigment, and a heart body (Banse 1969), as well as paired palps (Rouse \& Fauchald 1997), though whether any of these are apomorphic is not yet resolved as all of these features are found in other polychaete groups (Rouse \& Fauchald 1997).

Cirratulidae and, to an extent, Flabelligeridae were for many years 'dumping grounds' for taxa of uncertain affinities and both suffer from poorly understood phylogenies. Acrocirridae was erected from two genera previously included in Cirratulidae, Acrocirrus and Macrochaeta, by Banse (1969) who noted their similarity to flabelligerids on one hand and to the cirratulid genus Dodecaceria on the other. Acrocirridae grew with Orensanz (1974) transferring Flabelligella from Fauveliopsidae and Gillet (2001) then splitting Flabelligella when erecting Flabelligena. Laubier (1974) introduced Chanvinelia biscayensis as a flabelligerid, but Averincev (1980) moved the genus to Acrocirridae when describing a second species (Chauvinelia arctica). George \& Hartmann-Schröder (1985) aligned H. rankini with Phyllodocida, but Glasby \& Fauchald (1991) transferred it to Flabelligeridae. Helmetophorus rankini was then transferred, along with Flabelliseta (another flabelligerid), to Acrocirridae by Salazar-Vallejo et al. (2007). Thus, Acrocirridae currently consists of eight genera: Acrocirrus, Macrochaeta, Flabelligella, Flabelligena, Chauvinelia, Helmetophorus, Flabelliseta and Swima. Phylogenetic hypotheses based on morphological characters alone (Kristensen 1997; Rouse \& Pleijel 2003; Salazar-Vallejo et al. 2008) have returned various hypotheses for relationships within Flabelligeridae and Acrocirridae and there has been no attempt to date on Cirratulidae. Fauchald \& Rouse (1997) found no apomorphies to support monophyly of Acrocirridae, yet Rouse \& Pleijel's (2003) Cirratuliformia analysis recovered the clade in all shortest trees, with the homoplastic presence of 'pseudocompound' chaetae being an apomorphy for the clade. Salazar-Vallejo et al. (2007) offered an amended diagnosis, and Salazar-Vallejo et al. (2008) found the spinous nature of the chaetal surface was an apomorphy for Acrocirridae.

Analyses of DNA sequence data have also been used to assess relationships of Flabelligeridae and Acrocirridae
(Burnette et al. 2005; Osborn \& Rouse 2008; Osborn et al. 2009), but many questions remain, and a combined molecular and morphological approach has not yet been attempted. Here, we use morphological (29 characters) and molecular [18S, 28S, 16S, COI and Cytochrome B gene $(C y t B)$ sequences] evidence to reconstruct the evolutionary history of 17 flabelligerids and 11 acrocirrids, with seven cirratulids as nominal outgroups. Our objectives were to: (i) place the seven recently discovered acrocirrids in a stable phylogenetic framework in preparation for the description of the six remaining undescribed species (Osborn, Haddock \& Rouse in review; Osborn, Madin \& Rouse in review; Osborn \& Pleijel in prep.), (ii) use comparative methods to determine structure, function and homology of morphological features of acrocirrids and flabelligerids, (iii) elucidate historical relationships within Flabelligeridae and Acrocirridae and (iv) generate an evolutionary framework on which to assess questions about adaptations for life in the water column.

\section{Materials and methods Specimens}

Specimens of the seven recently discovered acrocirrids were recovered in varying conditions and preserved using several methods (70 or $95 \%$ ethanol, $2 \%$ sodium cacodylate buffered glutaraldehyde, 4-20\% formalin, or frozen in liquid nitrogen). The delicate nature of these species makes them particularly prone to preservation artifacts that vary by individual and fixation method. Relaxation in magnesium chloride in freshwater isotonic with seawater prior to fixation yielded the least distortion. Fixation in chilled $95 \%$ ethanol yielded specimens that were brittle, with the gelatinous sheath dehydrated to a point such that all external features could be clearly viewed. Fixation in formalin and glutaraldehyde yield specimens that looked more like live specimens. Contraction of the body occurred to some degree in all specimens, however, even unanesthetized specimens did not retract their heads to the point that they appear to have a cephalic hood. The portion of the body surrounding the anterior loop of the gut was consistently the first to deteriorate when the animal died or was damaged. Palps and short, elliptical or long, cylindrical branchiae were easily lost during handling but free-standing nuchal organs, digitate and subulate branchiae were not.

In order to resolve relationships of the seven recently discovered species to known Cirratuliformia, a range of benthic representatives of cirratuliforms were newly sequenced. All non-redundant and reliable flabelligerid and acrocirrid sequences from GenBank were included in this project, as well as several cirratulids to represent the span of cirratulid diversity (Table 2). Only taxa for which 
Table 2 GenBank and voucher accession numbers. Shaded pairs were concatenated. GenBank numbers in bold indicate new sequences

\begin{tabular}{|c|c|c|c|c|c|c|c|}
\hline Taxon & 185 & 285 & $\mathrm{COI}$ & CytB & 165 & Voucher & Locality \\
\hline \multicolumn{8}{|l|}{ Acrocirridae } \\
\hline Acrocirrus validus Marenzeller 1879 & FJ944491 & - & FJ944525 & FJ944538 & - & SIO BIC A1290 & Hayama, Sagami Bay, Japan ${ }^{a}$ \\
\hline Flabelligena sp. & EU694120 & EU694121 & EU694126 & EU694135 & EU694113 & SIO BIC A1126 & Pacific Antarctic Ridge ${ }^{\mathrm{b}}$ \\
\hline Macrochaeta clavicornis (Sars 1835) & EU791461 & - & EU791463 & - & HQ326957 & SIO BIC A1087 & Vattenholmen, Sweden ${ }^{\mathrm{b}}$ \\
\hline Macrochaeta clavicornis (Sars 1835) & - & DQ779696 & - & - & - & SMNH 75829 & Bohuslån, Sweden ${ }^{\mathrm{b}}$ \\
\hline Macrochaeta sp. & EU700414 & - & EU694125 & EU694136 & EU694114 & SIO BIC A1127 & Belize $^{b}$ \\
\hline Swima bombiviridis (PB51) & GQ422143 & GQ422144 & FJ944527 & FJ944540 & FJ944506 & SIO BIC A1282 & Monterey, California ${ }^{a}$ \\
\hline Shining bomber (sp. 1, PB32) & FJ944497 & - & FJ944531 & FJ944544 & - & SIO BIC A1285 & Monterey, California $^{a}$ \\
\hline Shining bomber (sp. 1, P1) & - & FJ944519 & - & - & - & SIO BIC A1286 & Monterey, California $^{a}$ \\
\hline Tawi-tawi Bomber (sp. 2) & FJ944499 & FJ944520 & FJ944533 & FJ944546 & FJ944511 & NMA 04327 & Celebes Sea, Philippines $^{\mathrm{a}}$ \\
\hline Horned Bomber (sp. 3) & FJ944500 & FJ944521 & FJ944534 & FJ944547 & FJ944512 & SIO BIC A1287 & Astoria Canyon, Oregon ${ }^{a}$ \\
\hline Tiburon Bomber (sp. 4) & FJ944501 & FJ944522 & FJ944535 & FJ944548 & FJ944513 & SIO BIC A1288 & Juan de Fuca Ridge, Oregon ${ }^{\mathrm{a}}$ \\
\hline Squidworm (sp. 5) & FJ944503 & FJ944524 & FJ944537 & FJ944550 & FJ944515 & NMA 04342 & Celebes Sea, Philippines ${ }^{\mathrm{a}}$ \\
\hline Juanita worm (sp. 6) & FJ944502 & FJ944523 & FJ944536 & FJ944549 & FJ944514 & SIO BIC A1289 & Juan de Fuca Ridge, Oregon ${ }^{\mathrm{a}}$ \\
\hline \multicolumn{8}{|l|}{ Flabelligeridae } \\
\hline Brada villosa (Rathke 1843) & EU791460 & EU791462 & - & - & HQ326962 & SIO BIC A1161 & Fiskebäckskil, Sweden ${ }^{\mathrm{b}}$ \\
\hline Brada villosa (Rathke 1843) & - & - & - & AY727747 & - & USNM 1073357 & Trondheimsfjord, Norway ${ }^{c}$ \\
\hline Brada sp. & HQ326967 & HQ326968 & HQ326970 & HQ326974 & HQ326963 & SIO BIC A1845 & Central California, USA \\
\hline Coppingeria cf. longisetosus Haswell & HQ326966 & - & HQ326971 & HQ326975 & HQ326960 & SIO BIC A1846 & Spencer Gulf, South Australia \\
\hline \multicolumn{8}{|l|}{1892} \\
\hline Diplocirrus glaucus (Malmgren 1867) & AY708534 & DQ790031 & - & AY727751 & - & USNM 1073353 & Gullmarsfjorden, Sweden, ${ }^{c, d}$ \\
\hline Diplocirrus glaucus (Malmgren 1867) & - & - & - & - & FJ944504 & SIO BIC A1139 & Kristineberg, Sweden ${ }^{a}$ \\
\hline Flabelliderma ockeri Salazar-Vallejo & EU694119 & - & EU694127 & EU694137 & EU694111 & SIO BIC A1129 & La Jolla, California, USA ${ }^{b}$ \\
\hline \multicolumn{8}{|l|}{2007} \\
\hline Flabelligera affinis Sars 1829 & AY708532 & - & - & - & - & USNM 1073354 & Gullmarsfjorden, Sweden ${ }^{c}$ \\
\hline Flabelligera affinis Sars 1829 & - & DQ779688 & - & - & DQ779614 & SAM E3562 & Iceland $^{\mathrm{e}}$ \\
\hline Flabelligera affinis Sars 1829 & AY708531 & - & - & AY727755 & - & USNM 1073355 & Central California, USA ${ }^{c}$ \\
\hline Flabelligera commensalis Moore 1909 & HQ326965 & - & - & HQ326972 & HQ326959 & SIO BIC A1843 & Malibu, California, USA \\
\hline Flabelligera infundibularis (Johnson & EU694118 & - & EU694131 & EU694133 & EU694112 & SIO BIC A1128 & Astoria, Oregon, USA \\
\hline \multicolumn{8}{|l|}{ 1901) } \\
\hline Flabelligera mundata Gravier 1906 & HQ326964 & - & HQ326969 & HQ326973 & HQ326958 & SIO BIC A1844 & South Orkney Islands, Antarctica \\
\hline Flota sp. & EU694116 & EU694110 & EU694128 & EU694134 & EU694110 & SIO BIC A1131 & Monterey, California, USA ${ }^{\mathrm{b}}$ \\
\hline Ilyphagus octobranchus Hartman 1965 & - & - & - & AY727749 & - & USNM 1073351 & Woods Hole, Massachusetts, USA \\
\hline Pherusa plumosa (Müller 1776) & AY708529 & - & - & AY727756 & - & USNM 1073348 & Woods Hole, Massachusetts, USA ${ }^{c}$ \\
\hline Pherusa plumosa (Müller 1776) & AY708528 & DQ790056 & - & AY727752 & - & USNM 1073356 & Central California, USA $A^{c, d}$ \\
\hline Piromis $s p$. & - & - & - & - & HQ326961 & LACM-AHF & Santa Monica, California, USA \\
\hline & & & & & & POLY 2264 & \\
\hline Poeobius meseres Heath 1930 & EU694115 & EU694123 & EU694130 & EU700415 & - & SIO BIC A1130 & Monterey, California, USA \\
\hline Poeobius meseres Heath 1930 & & - & - & - & DQ779631 & SAM E3563 & Monterey, California, USA ${ }^{\mathrm{b}}$ \\
\hline Therochaeta collarifera Ehlers 1887 & AY708527 & - & - & AY727753 & - & USNM 1073350 & Woods Hole, Massachusetts, USA ${ }^{c}$ \\
\hline \multicolumn{8}{|l|}{ Cirratulidae } \\
\hline $\begin{array}{l}\text { Aphelochaeta marioni (Saint Joseph } \\
\text { 1894) }\end{array}$ & DQ779639 & - & - & - & DQ779602 & SAM E3559 & Iceland $^{e}$ \\
\hline Dodecaceria concharum Örsted 1843 & AY577891 & DQ209242 & DQ209262 & - & - & SAM E3355 & Iceland $\mathrm{f}^{\mathrm{g}}$ \\
\hline Dodecaceria concharum Örsted 1843 & - & - & - & - & FJ965555 & SIO BIC A1141 & Bohuslån, Sweden ${ }^{a}$ \\
\hline Caulleriella sp. & - & DQ779679 & - & - & DQ779606 & SAM E3560 & Iceland ${ }^{e}$ \\
\hline Caulleriella parva Gillandt 1979 & AF448151 & - & - & - & - & - & Concarneau, France $^{\mathrm{h}}$ \\
\hline Cirratulus cirratus (Müller 1776) & DQ779645 & DQ779683 & - & - & DQ779609 & SAM E3561 & Iceland $^{e}$ \\
\hline Cirratulus spectabilis (Kinberg 1866) & AY708536 & DQ790029 & - & AY727746 & - & USNM 1073359 & Snug Harbour, Washington, USA $A^{c, d}$ \\
\hline Cirriformia tentaculata (Montagu 1808) & AY611456 & AY611443 & - & - & - & - & Banyuls, France ${ }^{i}$ \\
\hline $\begin{array}{l}\text { Ctenodrilus serratus serratus } \\
\text { (Schmidt 1857) }\end{array}$ & AY340426 & AY340388 & - & - & AY340452 & - & Massachusetts, USA ${ }^{e}$ \\
\hline
\end{tabular}

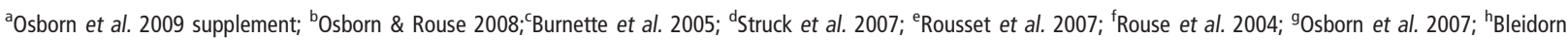
et al. 2003b; 'Rousset et al. 2004.

NMA, National Museum of the Philippines, Manila; SIO-BIC, Scripps Institution of Oceanography, Benthic Invertebrates Collection, La Jolla, California; USNM, National Museum of Natural History, Smithsonian Institution, Washington, DC; LACM-AHF POLY, Los Angeles County Museum of Natural History, Allen Hancock Foundation Polychaete Collection, Los Angeles, California. 
sequence data was available were included in analyses with the exception of Flabelligella, Flabelliseta, Helmetophorus and Chauvinelia for which it was critical to assess relationship to the new taxa and for which only morphological data could be generated. Fauveliopsis, Laubieriopsis and Sternaspis that were previously thought to be within Cirratuliformia (Rouse \& Pleijel 2001; Salazar-Vallejo et al. 2008) were not included because they may only be distantly related to the taxa considered here (e.g. Rousset et al. 2007; Struck et al. 2007). Of Cirratuliformia, the new species were most morphologically similar to acrocirrids and flabelligerids and least similar to cirratulids. Cirratulids were chosen as the root based on morphological (Rouse \& Fauchald 1997; Rouse \& Pleijel 2003; Salazar-Vallejo et al. 2008) and molecularly based (Burnette et al. 2005; Rousset et al. 2007; Struck et al. 2007) attempts to resolve relationships within Annelida.

The following specimens were examined for comparison with the seven recently discovered swimming acrocirrids:

Helmetophorus rankini Hartman, 1978

Holotype. USNM-46748, three paratypes USNM-46749, National Museum of Natural History, Smithsonian Institution, Washington, DC.

Chauvinelia biscayensis Laubier, 1974

Holotype. MNHN-1263, Muséum National d'Histoire Naturelle, Paris, three specimens were collected but only one was deposited.

Chauvinelia arctica Averincev, 1980

Non-type. ZMUC POL-0159. This single specimen was described by Kirkegaard (1982) from the FRAM I Drift Ice Expedition off of NE Greenland from Station 18 at 2300-3370 m and is deposited in the Zoological Museum, University of Copenhagen. The species was described from 17 specimens collected from the Canadian Trench in the Arctic at 3296-3380 m depth. These type specimens (Zoological Institute, Russian Academy of Sciences, Saint Petersburg) were unavailable for comparison.

The six recently discovered and as yet unnamed swimming acrocirrids are here given colloquial names so that their relationships and morphology can be individually discussed (Fig. 1; Table 1).

\section{Sequence data}

Genomic DNA was extracted from specimens using a Qiagen DNeasy tissue kit (Valencia, CA, USA). An approximately 1800 base pair fragment of the small subunit ribosomal DNA (18S) was amplified with the universal primers mitchA and mitchB (Medlin et al. 1988) or TimA and TimB (Norén \& Jondelius 1999) with 35 ramping cycles of: $94{ }^{\circ} \mathrm{C}$ for $60 \mathrm{~s}, 56-64{ }^{\circ} \mathrm{C}$ for $60 \mathrm{~s}, 72{ }^{\circ} \mathrm{C}$ for $90 \mathrm{~s}$, initial denaturation at $94{ }^{\circ} \mathrm{C}$ for $3 \mathrm{~min}$, final extension at $72{ }^{\circ} \mathrm{C}$ for $5 \mathrm{~min}$. Approximately 1100 base pairs of the large subunit ribosomal DNA (28S) were amplified with the universal primers LSUD1F and D3ar (Lenaers et al. 1989) or C1 and R4 (Lê et al. 1993 and Struck et al. 2006; respectively) with $30-35$ cycles of $94^{\circ} \mathrm{C}$ for $60 \mathrm{~s}$, $57-60{ }^{\circ} \mathrm{C}$ for $60 \mathrm{~s}, 72{ }^{\circ} \mathrm{C}$ for $80 \mathrm{~s}$, initial denaturation at $94^{\circ} \mathrm{C}$ for $3 \mathrm{~min}$, final extension at $72{ }^{\circ} \mathrm{C}$ for $5 \mathrm{~min}$, optionally with 5 cycles of $94{ }^{\circ} \mathrm{C}$ for $60 \mathrm{~s}, 52^{\circ} \mathrm{C}$ for $60 \mathrm{~s}$, $72{ }^{\circ} \mathrm{C}$ for $80 \mathrm{~s}$ preceding the 30 cycles above. A $350-500$ base pair fragment of the mitochondrial small subunit ribosomal DNA (16S) was amplified either using the universal primers $16 \mathrm{SarL}$ and $16 \mathrm{SbrH}$ (Palumbi et al. 1991) or the annelid specific primers AnnF and AnnR (Sjölin et al. 2005) with $30-35$ cycles of $94^{\circ} \mathrm{C}$ for $40 \mathrm{~s}, 45-49^{\circ} \mathrm{C}$ for $40 \mathrm{~s}, 72{ }^{\circ} \mathrm{C}$ for $45 \mathrm{~s}$, initial denaturation at $94{ }^{\circ} \mathrm{C}$ for $3 \mathrm{~min}$, final extension at $72{ }^{\circ} \mathrm{C}$ for $5 \mathrm{~min}$, optionally with 5 cycles of $94{ }^{\circ} \mathrm{C}$ for $40 \mathrm{~s}, 45^{\circ} \mathrm{C}$ for $40 \mathrm{~s}, 72{ }^{\circ} \mathrm{C}$ for $45 \mathrm{~s}$ preceding the 30 cycles above. Approximately 650 base pairs of the mitochondrial COI gene were amplified using universal primers HCO2198 and LCO1490 (Folmer et al. 1994) with 5 cycles of: $94{ }^{\circ} \mathrm{C}$ for $30 \mathrm{~s}, 45^{\circ} \mathrm{C}$ for $90 \mathrm{~s}$, $72{ }^{\circ} \mathrm{C}$ for $60 \mathrm{~s}, 30$ cycles of $94^{\circ} \mathrm{C}$ for $30 \mathrm{~s}, 51^{\circ} \mathrm{C}$ for $90 \mathrm{~s}$, $72{ }^{\circ} \mathrm{C}$ for $60 \mathrm{~s}$, initial denaturation at $94{ }^{\circ} \mathrm{C}$ for $60 \mathrm{~s}$, final extension at $72{ }^{\circ} \mathrm{C}$ for $5 \mathrm{~min}$. Approximately 360 base pairs of the $C y t B$ were amplified via the universal primers $424 \mathrm{~F}$ and $876 \mathrm{R}$ (Boore \& Brown 2000) with 35 ramping cycles of $94{ }^{\circ} \mathrm{C}$ for $45 \mathrm{~s}, 42^{\circ} \mathrm{C}$ for $45 \mathrm{~s}, 72^{\circ} \mathrm{C}$ for $45 \mathrm{~s}$, initial denaturation at $94{ }^{\circ} \mathrm{C}$ for $3 \mathrm{~min}$, final extension at $72{ }^{\circ} \mathrm{C}$ for $5 \mathrm{~min}, 4 \mu \mathrm{l}$ of $25 \mathrm{mM} \mathrm{Mg}(\mathrm{OAc})_{2}$ was added to each reaction. Twenty-five microliter reactions were carried out using either Illustra PuReTaq Ready-To-Go PCR Beads (GE Healthcare, Uppsala, Sweden) or Promega GoTaq Green (Madison, WI, USA). Amplification profiles were optimized for each extraction.

The PCR products were sequenced directly after spin column purification (Ultrafree-DA columns; Millipore, Billerica, MA, USA) following the manufacturers' protocols. All sequencing was carried out using the same primers that were used in the amplification, with the addition of four internal primers for $18 S$ (600F, 4FBK Norén \& Jondelius 1999; a2.0, bi; Giribet et al. 1999). All sequencing was carried out by Advanced Studies in Genomics, Proteomics and Bioinformatics (ASGPB) at the University of Hawaii at Manoa using Applied Biosystems (Calsbad, CA, USA), BigDye terminator chemistry and an ABI 3730XL sequencer. $C y t B$ sequences are forward reads only because sequencing reactions were never successful with reverse primers (also 825R referenced in Burnette et al. 2005 was tried unsuccessfully). Sequences were deposited in GenBank (Table 2).

\section{Morphology}

A 29 character morphological matrix was compiled (Appendix S1) after consideration of previous morphologi- 
cal analyses (Rouse \& Fauchald 1997; Rouse \& Pleijel 2003; Salazar-Vallejo et al. 2008) in order to examine relationships of the new taxa to each other, to Flabelligeridae, and to Acrocirridae. The matrix included all species for which we had sequence data, as well as four species for which sequence data could not be obtained, but whose relationships to the new species were of interest (C. arctica, H. rankini, Flabelliseta incrusta Hartman 1978; and Flabelligella sp.). Characters were coded from type material whenever possible or from non-type material, original descriptions or recent revisions. See Appendix S1 for characters and the supplemental online material for discussion of characters. The matrix is also available at Treebase (http://www.treebase.org).

\section{Analyses}

Sequences were concatenated only when from the same extraction, except in eight cases for which extracts were not available (Table 2 shaded pairs). Sequences were aligned with MUSCLE 3.6 (Edgar 2004) using default settings and proofread by eye in MacClade v.4.04 (Maddison \& Maddison 2000). Possibly ambiguously aligned bases were not excluded from ribosomal genes alignments in favour of total evidence. Individual ribosomal alignments consisted of the following: $18 S$ was 2177 base pairs, 1409 constant or uninformative, 768 informative; $28 S$ was 1139 base pairs, 503 constant or uninformative, 636 informative; $16 S$ was 567 base pairs, 275 constant or uninformative, 292 informative. Third positions were not saturated for $\mathrm{COI}$ with respect to the ingroup or outgroup (DAMBE; Xia et al. 2003), thus all positions were included in the analysis (684 base pairs, 413 constant or uninformative, 271 informative). $C y t B$ third positions were saturated with respect to both ingroup and outgroup taxa and thus were excluded from all final analysis runs (390 base pairs, 130 excluded, 181 constant or uninformative, 79 informative; inclusion of third positions had no impact on support or topology in the combined analyses).

Bayesian analyses of the data sets were conducted using MrBayes 3.1.2 (Huelsenbeck \& Ronquist 2001) through the Cornell University Computation Biology Service Unit. Standard procedures based on Modeltest 3.5 (Posada \& Crandall 1998) were implemented in PAUP* $4.0 \mathrm{~b} 10$ to select the most appropriate models for individual genes. The relative fit of models was assessed by the Akaike information criterion. Smaller values of Akaike information criterion are preferred (Akaike 1974; Posada \& Crandall 2001) and the General Time Reversible + Proportion Invariant + Gamma $(G T R+I+\Gamma)$ represented the optimal model with respect to all genes. Partitions were unlinked in the concatenated analyses. Each Markov chain, three heated and one cold, was started from a random tree and all four chains were run simultaneously for 5 to 60 million generations, with trees being sampled such that the resulting data set from each run contained at least 10000 data points after burn-in. AWTY (Wilgenbusch et al. 2004) was used to determine if a sufficient number of generations had been completed for posterior probabilities to stabilize, as well as to determine amount of required burn-in before inference from the Markov chain Monte Carlo data sets were made. Numerous repeated analyses converged on similar parameter estimates.

Maximum likelihood analyses were conducted with RAxML 7.2.6 (Stamatakis 2006) on the CIPRES Portal (Miller et al. 2009) as a partitioned dataset (each gene and each codon position as in the Bayesian analyses) and the General Time Reversible + Gamma $($ GTR $+\Gamma)$ model was used. 'Multiparametric' bootstrapping (command-b = non-parametric bootstrapping) with random seed value: 12345 was carried out in each case with a minimum of 100 replicates, also using GTR + G.

Parsimony analyses of molecular data were conducted with PAUP* 4.0b10 (Swofford 2002) using an equally weighted character matrix, the heuristic search option, the tree-bisection-reconnection branch-swapping algorithm, and 1000 random addition replicates. Gaps were treated as missing data. Bootstrap values were obtained with the same settings as the parsimony analysis (1000 replicates).

Parsimony analyses were run on the morphological matrix alone, on the combined morphological and molecular matrix containing only species for which there were both type of data, and on the combined morphology and molecular matrix containing all species. Parsimony settings were as described above from molecular data. Bayesian analyses with settings as described above were also run on the combined molecular and morphological matrixes with the addition of a rate variable model used for the morphology partition.

\section{Results \\ Gene trees}

Some general themes were seen in the individual gene trees (Fig. 2). Strong support was consistently found for the seven recently discovered species forming a clade (containing S. bombiviridis, 'Shining', 'Tawi-tawi', 'Horned', and 'Tiburon Bombers', 'Juanita worm' and 'Squidworm') and for that clade being within the monophyletic Acrocirridae. The monophyly of Flabelligeridae and their sister relationship to Acrocirridae was recovered in all but the $C O I$ and $C y t B$ analyses. The position of Flabelligena sp. was variable in the various genes, though it was always outside of both the Acrocirrus/Macrochaeta clade and the clade containing the seven recently discovered swimming species (hereafter referred to as the 'Swimming clade' Fig. 3). A 


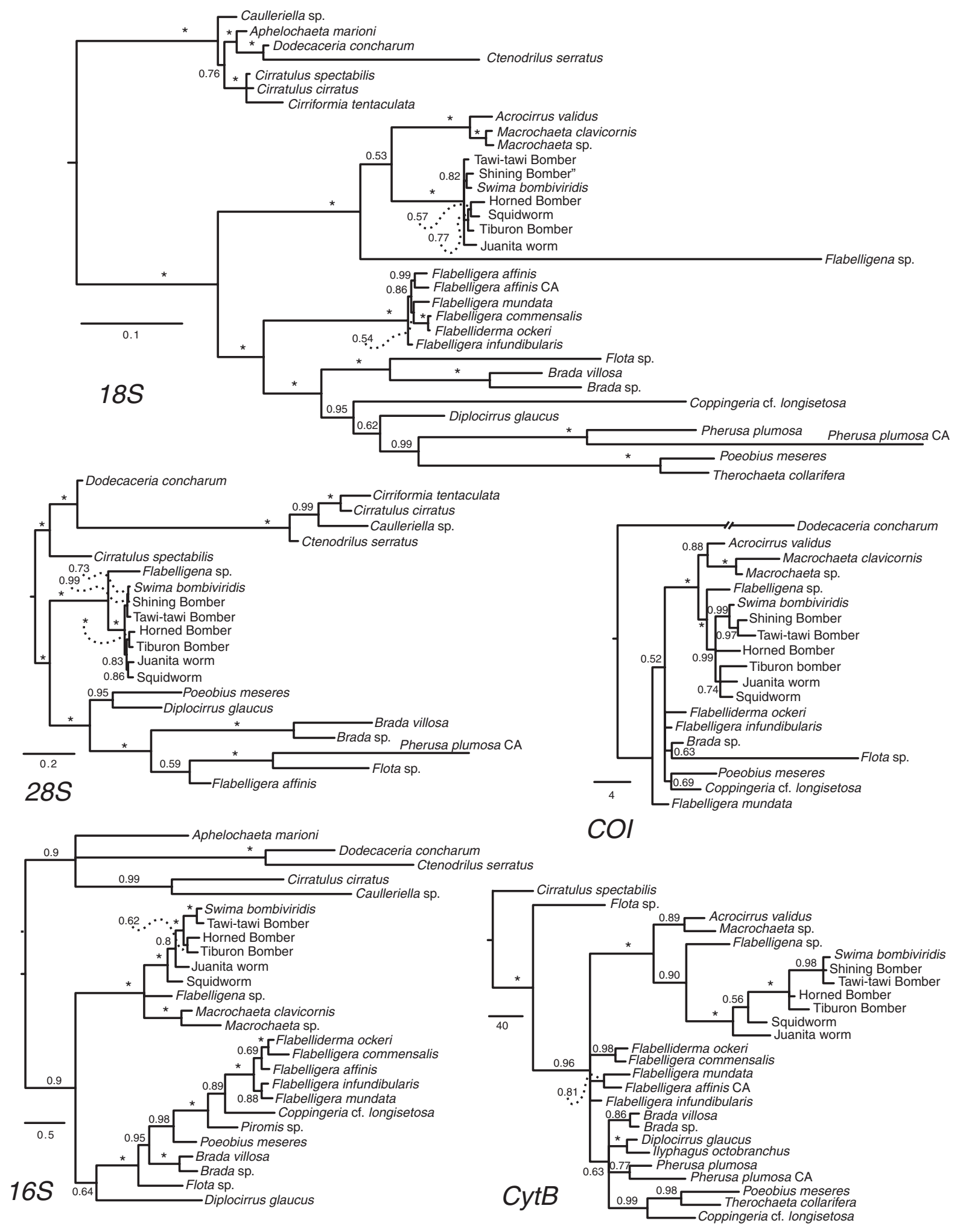

Fig. 2 Majority rule consensus trees from Bayesian analyses of individual genes. Protein coding genes were partitioned by first, second and third positions and third positions were excluded in the $C y t B$ analyses. Support values are shown as posterior probabilities. Asterisks indicate 1.0 posterior probabilities. 


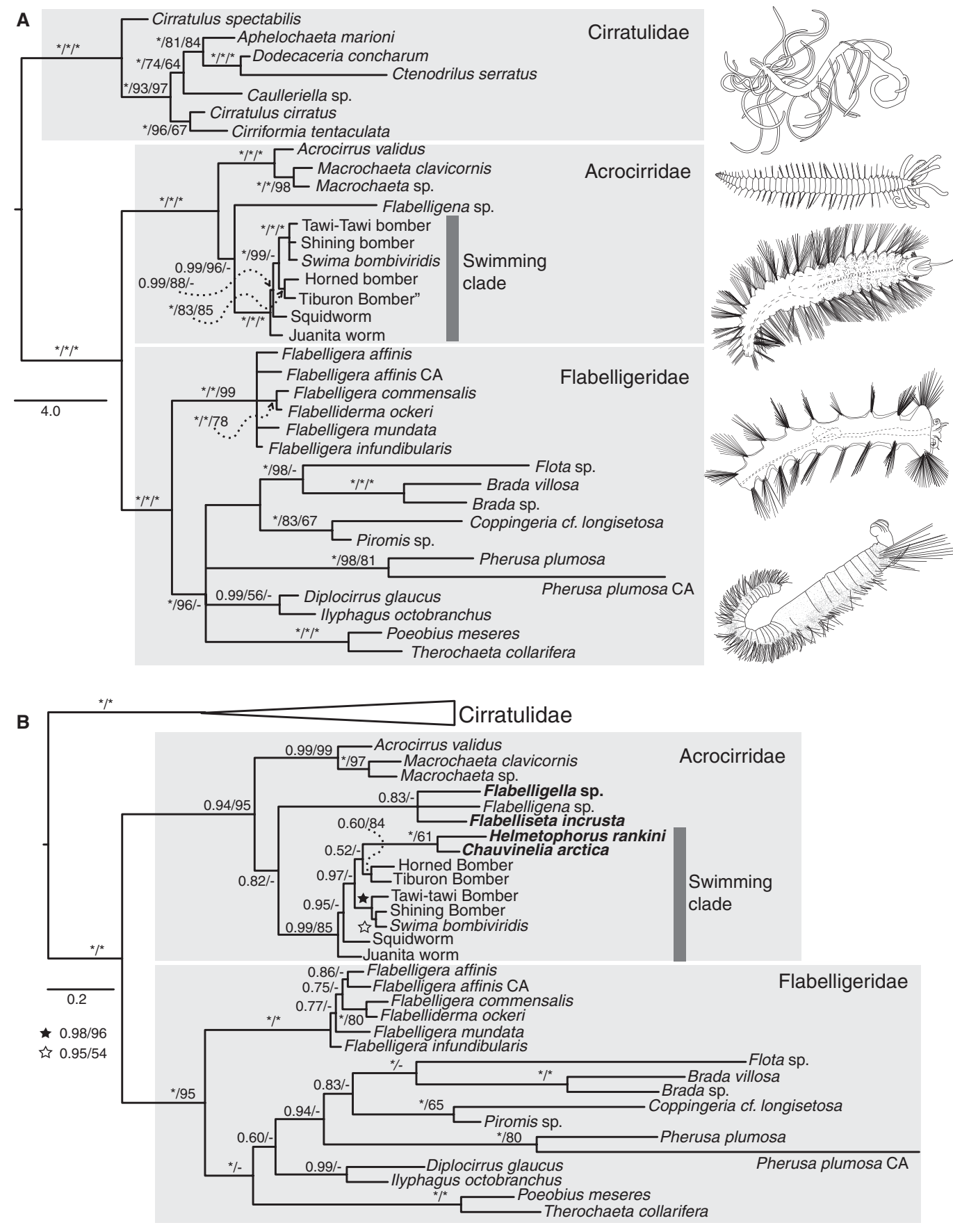

Fig. 3 -A. Ninety-five percent majority rule consensus tree from Bayesian analyses of five concatenated genes and the morphological matrix. Data were partitioned by each gene and the morphological matrix, and by first, second and third codon positions. $C y t B$ third positions were excluded. The topology of the RAxML tree (GTR + G model) did not differ from the Bayesian tree, however, the strict consensus tree from the parsimony analysis differed in that Squidworm and Juanita worm formed a clade with $91 \%$ bootstrap support and that clade formed a polytomy with Swima sensu stricto and the Horned/Tiburon Bomber clades. Support is indicated as posterior probabilities from the Bayesian analysis/bootstraps from the maximum likelihood analysis/bootstraps from the parsimony analysis. Asterisks indicate 1.0 or $100 \%$ support respectively. Illustrations of a representative cirratulid, acrocirrids Acrocirrus validus and Swima bombiviridis, and flabelligerids Flota sp. and Pherusa plumosa CA are given to the right. - B. Majority rule consensus tree from Bayesian analyses of five concatenated genes and 29 morphological characters including four species (bold) for which only morphological data was available (all other analysis parameters are the same as in A). Based on the limited information provided by the morphological data and the large amount of missing data for these four taxa, all support values decreased within Acrocirridae where the added taxa fell. 
sister relationship between Flabelliderma ockeri Salazar-Vallejo 2007 and Flabelligera commensalis Moore 1909 was recovered for all genes (18S, $16 \mathrm{~S}$ and $\mathrm{CytB})$ that included both species. The relatively long branch lengths within the non-Flabelligera/Flabelliderma flabelligerids $18 S$ and $28 S$ analyses were also notable.

The $18 S$ data provided poor resolution within the Swimming clade (Fig. 2). Within Flabelligeridae the 185 data strongly supported the following: (i) distinction of Flabelligera/Flabelliderma from other flabelligerids, (ii) monophyly of each of the included Pherusa, Brada, and Flabelligera/Flabelliderma and (iii) sistergroup relationships between Brada/Flota sp., as well as between P. meseres/Therochaeta collarifera Ehlers 1887. Additionally $18 S$ data suggested a sister relationship between included Pherusa spp. and P. meseres/T. collarifera.

The $28 S$ data provided strong support for a clade containing Horned and Tiburon Bombers, as well as one containing S. bombiviridis and Shining and Tawi-tawi Bombers (Fig. 2). Swima is here restricted to those three species that consistently grouped together within the Swimming clade based on sequence data and that possess the following characters: transparent body, thick gelatinous sheath, nuchal organs as simple ridge with no more than one $180^{\circ}$ bend, small 'bombs' (elliptical, segmental branchiae that bioluminesce when autotomized, measuring less than half widest body width), and single medial subulate branchia on head. Thus, Swima sensu stricto consists of S. bombiviridis, Shining and Tawi-tawi Bombers. Strong support was also found for a relationship between Flota sp. and the included Pherusa, a result not found with other genes.

The $16 \mathrm{~S}$ data provided a reasonable amount of variability across the acrocirrids and flabelligerids sampled, as seen by the relatively intermediate branch lengths compared to other genes sampled (Fig. 2). Strong support was provided for a sister relationship between Swima sensu stricto and the clade of Horned and Tiburon Bombers. Interestingly $16 \mathrm{~S}$ placed the Flabelligera/Flabelliderma clade as relatively derived among flabelligerids in contrast to the group's more basal position in other gene trees.

While the COI data were useful in identifying species groups (Osborn et al. 2009; Osborn, Haddock and Rouse, in review), it provided little resolution of relationships for phylogenetic analyses (Fig. 2). Cyt $B$ data provided good resolution within the portion of the tree that had short branches for other genes (i.e. within the Swimming clade), yet similar to $C O I$, provided little information about more distant relationships. Analyses of $C y t B$ sequences, unlike those of COI, found similar relationships, although with low support, to that found in other genes.

\section{Morphology}

Morphology alone provided little insight into the relationships within and between Flabelligeridae and Acrocirridae (Fig. S1). Body papillae united Flabelligeridae and Acrocirridae and distinguished them from Cirratulidae. The shape of the prostomium further distinguished cirratulids from acrocirrids and flabelligerids, as well as most flabelligerids from acrocirrids ( $P$. meseres is similar to that of the acrocirrids). Monophyly of Flabelligeridae was recovered in the parsimony analysis of the morphological matrix (Fig. S1), supported by presence of the following: branchial membrane (with the exception of sharing this character with Squidworm and Juanita worm), retractable head, cephalic hood (present also in the acrocirrids H. rankini and C. arctica), and cephalic cage (though lost in Brada spp., Flota spp., P. meseres and Diplocirrus spp.). The texture of the chaetae (Fig. S2) distinguished the families considered here; cirratulids possess smooth chaetae, acrocirrids have fine denticles on the surface and flabelligerids have segmented or cross-barred chaetae (Flabelligella spp. may share this feature with flabelligerids). The parsimony analysis of the morphological matrix did not recover a monophyletic Acrocirridae, despite the chaetal apomorphy. The following characters were shared among various members of Acrocirridae and Flabelligeridae but were not found in Cirratulidae: sediment adhered to epidermis, gelatinous sheath, nephridiopore as a papillus, parapodia distinct projections from the body wall, and compound chaetae.

Elliptical main branchiae supported a clade containing Swima sensu stricto, Horned and Tiburon Bombers, H. rankini, and possibly C. arctica. Helmetophorus rankini and Chauvinelia spp. share several characteristics with Swima sensu stricto and Horned and Tiburon Bombers. All possess subulate branchiae occurring in one or more rows just behind or medial to the nuchal organs. These subulate branchiae are not found in any other Cirratuliformia examined and each species that possesses them also has at least one other branchial form. Helmetophorus rankini, Swima sensu stricto and Horned and Tiburon Bombers all share elliptical main branchiae (Chauvinelia spp. may as well, but it cannot be determined based on the material, branchial scars are found on at least two anterior, achaetous segments similar to that found in all species bearing elliptical branchiae). Additionally, H. rankini, Chauvinelia spp. Swima sensu stricto and Horned and Tiburon Bombers have fans of numerous long chaetae, a feature shared with the other two members of the Swimming clade as well (Juanita worm and Squidworm).

Squidworm and Juanita worm are distinct from other known acrocirrids based on the their free-standing nuchal structures, a branchial membrane supporting four pairs of 
elongate, tapered main branchiae and the presence of the nephridiopore on the branchial membrane. Additionally, these two species, along with Swima sensu stricto and Horned and Tiburon Bombers, share two notable (though convergent) features with Flabelligeridae, gonads in discrete anterior segments and looped guts (shared also with Chauvinelia spp. and H. rankini).

\section{Combined analyses}

There was little difference between the combined molecular only (Fig. S4) and combined morphology and molecular analyses (Fig. 3a). The seven new species formed a single, well-supported clade that was within Acrocirridae in all analyses (Fig. 3, Fig. S4), distinguished here as four groups. Swima sensu stricto, containing S. bombiviridis, Shining and Tawi-tawi Bombers, was well-supported in all analyses and was most derived relative to the other swimming forms. Tiburon and Horned Bombers were sistergroup to Swima sensu stricto and were well-supported by all except the analysis including taxa with only morphological data (Fig. 3b), where support decreased for all clades within Acrocirridae. Two morphologically and molecularly distinct taxa were also found, Squidworm and Juanita worm. Parsimony analysis of the combined dataset suggested with low support that these groups may be sister to each other, but this result was not recovered in any other analyses. Instead, the relationship of these two groups remained unresolved within the Swimming clade (Fig. 3). Based on morphology, the swimming clade also includes H. rankini and C. arctica (Fig. 3b, Fig. S3), species that were most similar morphologically to Horned and Tiburon Bombers.

Within Acrocirridae, the included Acrocirrus and Macrochaeta species formed a well-supported clade in all analyses. The relationship of Flabelligena sp. to other acrocirrids was variable, generally falling out as sister to the swimming clade or in a basal polytomy with the Acrocirrus/Macrochaeta and Swimming clades (Figs. 3, Fig. S4). Similarly, the addition of $F$. incrusta and Flabelligella sp. to the analysis found them also in the acrocirrid basal polytomy (Fig. 3b).

The addition of molecular data for Piromis sp., Coppingeria cf. longisetosus Haswell 1892; an additional Brada sp., Flabelligera mundata Gravier 1906 and F. commensalis Moore 1909 provided further resolution within the Flabelligeridae and clarified the sister relationship between Flabelligeridae and Acrocirridae compared to that found in previous attempts (Osborn \& Rouse 2008; Osborn et al. 2009). Notably Flabelligeridae was found to form a clade rather than a grade. As with previous results a Flabelligera/Flabelliderma clade was strongly supported, Brada spp. and Flota sp. remained sister to each other, as did P. meseres and
T. collarifera (Fig. 3). Coppingeria cf. longisetosus and Piromis sp. may be more closely related to Brada/Flota than to other flabelligerids, but support was not consistently strong across analyses (Fig. 3).

The addition of species for which only morphological data was available (C. arctica, H. rankini, Flabelligella sp. and F. incrusta Hartman 1978) to the combined molecular and morphological analyses did not change the topology of the tree with respect to the taxa for which both types of data were available (Fig. 3b). However, these additions decreased the support for all nodes within Acrocirridae where the additional taxa fell.

\section{Discussion}

\section{Taxonomy}

Swima was originally delineated as a clade of seven swimming species in the Osborn et al. (2009) tree, but is here restricted to only the three species (including the type species S. bombiviridis) with the following apomorphies: a medial subulate branchia, one row of subulate branchiae (sometimes consisting of only the medial branchia), nuchal organs as slightly raised ridges making no more than one $180^{\circ}$ bend, and short segmental, ellipsoid branchiae. The description of the two undescribed Swima species, Tawitawi and Shining bombers is forthcoming (Osborn, Haddock and Rouse, in review). The remaining four species will be divided into three new genera (Horned and Tiburon Bombers forming one and Squidworm and Juanita worm each forming monotypic taxa) derived from morphology and a well-supported tree topology based on all currently available evidence. Chauvinelia and Helmetophorus are certainly related to these new groups but without genetic data and clear understanding of the nature of the achaetous anterior region of $H$. rankini and Chauvinelia spp., we retain these as separate genera.

Helmetophorus rankini is most similar to Horned and Tiburon Bombers, sharing the following characters: multiple rows of subulate branchiae, relatively large 'foliose' or elliptical segmental branchiae and nuchal organs as convoluted ridges winding among the bases of the subulate branchiae. Helmetophorus rankini differs from all other members of the Swimming clade in the following characters: its small size $(6 \mathrm{~mm}$ long, $0.8 \mathrm{~mm}$ wide compared with the smallest species of the swimming clade, S. bombiviridis, which, even when preserved, reaches at least $11 \mathrm{~mm}$ length and $2.1 \mathrm{~mm}$ width), a uniramous first chaetiger (notochaetae only), a non-retractile oral tube and a cephalic hood projecting anteriorly on the dorsum. Helmetophorus rankini differs from Horned and Tiburon Bombers most notably in having only simple neurochaetae. The small size and poor condition of $H$. rankini specimens make it impossible to determine if more than two pairs of 
elliptical branchiae were once present as is suspected. Also, the nature of the cephalic hood is questionable (see discussion of characters 1 and 2 in Supplemental Materials and Methods).

Chauvinelia spp. are also most similar to Horned and Tiburon Bombers, similarly possessing multiple rows of subulate branchiae and nuchal organs as convoluted ridges winding among the bases of the subulate branchiae. Chauvinelia spp. differ from Horned and Tiburon Bombers in possessing the following characters: a thick gelatinous sheath, semi-transparent body, and the inflated and elongate, anterior, featureless, achaetous segments. While Horned and Tiburon Bombers have achaetous, anterior segments, these segments are muscular, not inflated, have branchiae, and the head is never retracted inside of these segments irrespective of handling and fixation. The gelatinous sheath of Horned and Tiburon Bombers is thin, sometimes has a minute layer of fine sediment particles embedded in it, and is apparent only when it is damaged or around the bases of the chaetae. The branchial scars on the achaetous segments clearly drawn by Averincev (1980) and referred to as 'indistinct swellings' are difficult to distinguish on the infolded body wall of Kirkegaard's (1982) specimen (Fig. 1), but appear to be similar to the scars left by the ellipsoid branchiae of the Bombers. The nature of these lost branchiae is unknown for Chauvinelia species.

Retractability of the head and the nature of the cephalic hood of Helmetophorus and Chauvinelia are problematic when trying to understand these two taxa's relationships to members of the Swimming clade. Missing information due to the limited number of specimens known for each species the delicate nature of the worms that leads to poor condition upon collection and preservation, and the lack of information about the live animals are problematic.

In addition to their cephalic hoods, Chauvinelia spp. and $H$. rankini both have multiple rows of subulate branchiae surrounded by a convoluted ridge that forms the nuchal organs. These two taxa differ in the thickness of their gelatinous sheaths, with that of Chauvinelia spp. being relatively thick, while H. rankini has a thin sheath (see Supplemental Materials and Methods). Additionally, Chauvinelia spp. have compound neurochaetae while those of $H$. rankini are simple. These two species also differ in general size, Chauvinelia spp. being longer and wider (6-17.5 mm long and 1.2$2.8 \mathrm{~mm}$ wide) than H. rankini (less than $6 \mathrm{~mm}$ long and $1 \mathrm{~mm}$ wide). Salazar-Vallejo et al. (2007) were the first to compare these taxa and they did not consider synonymizing them despite their similarities. We also maintain them as separate taxa consistent with traditional morphological taxonomy. Until further specimens of Chauvinelia and Helmetophorus can be obtained from which genetic material can be extracted and the nature of the segmental branchiae and cephalic hood can be determined, the question of their relationships to the remainder of the Swimming clade cannot be fully resolved.

\section{Morphology}

The ontogeny of flabelligerid branchiae is unknown. Details of the circulatory system provided by Schlieper (1927) and Spies (1973) both suggest origin of the branchiae posterior to the peristomium. Additionally, Rouse \& Pleijel (2001) argued that the branchiae are segmental because the single, large pair of nephridia opens onto the branchial membrane and if this were a peristomial structure, the position of the nephridiopores would be novel within Annelida. Our observations show that the nephridiopores of Pherusa plumosa CA are located at the bases of the second from lateral branchiae and are similarly located in Squidworm and Juanita worm. Likewise, the nephridiopore of Dipplocirrus longisetosus (Marenzeller 1890) is also at the bases of the second branchiae on the branchial membrane (Filippova et al. 2003). Acrocirrids have a single large pair of anterior nephridia and a pair of papillae on the second chaetiger that is the nephridiopore. Although these papillae have been clearly illustrated by most authors since Banse (1969) their connection to the nephridia has not been confirmed, likely due to the small size of many acrocirrids. Observations of the internal anatomy of members of the Swimming clade allowed recognition of the function of these structures. The location of the nephridiopore on the second segment in acrocirrids, the close relationship of acrocirrids to flabelligerids, the location of the nephridiopore at the base of the second branchiae in Squidworm and Juanita worm, and the location of the nephridiopore next to the second branchiae in P. plumosa CA and D. longisetosus all suggest that flabelligerid branchiae are likely segmental in origin.

\section{Phylogenetics}

Our analyses confirmed Acrocirridae as a clade including all seven recently discovered swimming species (Osborn et al. 2009), as well as Helmetophorus and Chauvinelia as hypothesized by Salazar-Vallejo et al. (2007). We found that the seven new species form a clade within Acrocirridae along with Helmetophorus and Chauvinelia. A revised diagnosis of Acrocirridae is provided to reflect this increased morphological diversity.

Our analyses also confirmed the validity of Flabelligeridae as a clade and their sister relationship to Acrocirridae. Addition of sequence data for seven key taxa since Osborn et al. (2009) resulted in recovery of Flabelligeridae as a clade and not a grade as was found previously. Numerous apomorphies also support Flabelligeridae as separate from Acrocirridae (Fig. S3). 
Retention of Flabelliderma may render Flabelligera paraphyletic. This synonymy was indirectly suggested by earlier workers' confusion between the genera, recent transfer of species between them (e.g. Salazar-Vallejo 2007), and the instability of F. commensalis (Hartman 1969; Fauchald 1997; Light 1978; Salazar-Vallejo 2007). Salazar-Vallejo (2007) noted three main apomorphies for a Flabelligera/Flabelliderma clade, (i) chaetae of the cephalic cage arranged in a single row, forming a nearly complete circle around the head, (ii) head only moderately, if at all, eversible and (iii) pseudocompound neurohooks. Our finding of Flabelliderma ockeri Salazar-Vallejo 2007 as most closely related to $F$. commensalis suggests that either F. commensalis belongs in Flabelliderma or that Flabelliderma is nested within Flabelligera (Fig. 3). A detailed phylogenetic analysis containing multiple examples of Flabelliderma and Flabelligera is needed to resolve this question.

The position of Flabelligella and Flabelligena within Acrocirridae was unresolved. These two genera may be sister to either the Acrocirrus/Macrochaeta clade or the Swimming clade. Additionally, sequence data is needed for F. incrusta, H. rankini and Chauvinelia spp. to better understand their relationships within Acrocirridae. The long branches and unresolved relationships between the included flabelligerids beg further study with increased taxon sampling for DNA sequencing.

Finally, the ecological and behavioural information we have for the seven recently discovered members of the Swimming clade combined with these phylogenetic results suggest an evolutionary transition from the nearly benthic Juanita worm, through the benthopelagic Squidworm, Horned and Tiburon Bombers to the holopelagic members of Swima sensu stricto. This transition, together with the three separate origins of pelagic lifestyle within Cirratuliformia (Osborn et al. 2009) presents an ideal system to examine pelagic adaptations within Annelida.

\section{Systematics}

Family ACROCIRRIDAE Banse, 1969

Type genus Acrocirrus Grube, 1873 by original designation.

Diagnosis (emended). Free-living polychaetes with spinous chaetae that are most easily observed at distal tips. Notochaetae capillary, rarely lacking. Neurochaetae pseudocompound hooks or compound spinigers or hooks, rarely with posterior neurochaetae simple. Frontal grooved palps, easily lost but leaving obvious scars. Reduced prostomium dorsal on peristomium. Mouth opening subterminal, proboscis unarmed, with a buccal sac. With or without eyes. Nuchal organs straight, variously convoluted ciliated bands, or extending onto free-standing, oppositely branched and/or spiral structures. Sometimes with one or more rows of subulate branchiae surrounded by nuchal ridges. Usually with achaetous anterior segments, sometimes with anterior segments fused. Sometimes with transparent, gelatinous sheath. Usually with four pairs anterior segmental branchiae, easily lost, dorsal to notopodia, long, digitiform to short, elliptical. Pair of large anterior nephridia, nephridiopores ventral to second pair segmental branchiae, often as elongate papillae. Gonoducts in two or three anterior segments or in numerous abdominal segments. Epidermis with papillae, interramal papillae prominent. Gut straight or looped.

Swima Osborn et al. 2009

Type species, Swima bombiviridis, by original designation

Diagonsis (emended). Swimming acrocirrids with thick gelatinous sheath penetrated throughout by long, clavate papillae. Body transparent. One or more lollipop-shaped, interramal papillae projecting well beyond gelatinous sheath. With more than 30 long (more than body width) chaetae per parapodium. Eyes absent. Head not retractable. Nuchal organs just posterior to palps as simple, slightly raised ciliated ridges making no more than single $180^{\circ}$ bend. Possessing single, medial subulate branchia either individually or as part of a single row of subulate branchiae immediately posterior to palps and anterior to segmental branchiae, not easily lost. Sometimes with single row of more than 30 digitiform branchiae just posterior to subulate branchiae. Nephridiopores as papillae on second achaetous segment. Four pairs of segmental branchiae modified as ellipsoid, bioluminescent structures, the second of which is attached to basal portion of nephridiopore papillae. Segmental branchiae small (largest less than half width widest body), easily lost, leaving obvious circular scars.

\section{Acknowledgements}

Our sincere thanks are extended to Bruce Robison, Steve Haddock and Ken Smith for invitations to KJO to go to sea. Thanks also to Steve Haddock, Fredrick Pleijel and Larry Madin who discovered S. bombiviridis (SHDH), Tiburon bomber and Juanita worm (FP), Squidworm and Tawi-tawi bomber (LPM). Thanks also to those who provided various specimens: Ejiroh Nishi for A. validus, Celeste Benham for Flabelligera commensalis, Nerida Wilson for Flabelligera mundata, and Sergio Salazar-Vallejo, Leslie Harris, and Larry Lovell for Piromis. Funding was provided to KJO by a University of California President's Postdoctoral Fellowship and to GWR by Scripps Institution of Oceanography. Bayesian analyses were run at the Cornell University Computation Biology Service Unit. Maximum likelihood RAxML 
analyses were run on the CIPRES Portal 2.2 at UCSD. Thanks goes to the crew of the $\mathrm{R} / \mathrm{V}$ Western Flyer, the pilots of the ROVs Tiburon and Doc Ricketts, and the MBARI video lab staff for their dedication to deep-sea exploration. Evelyn York and Sara Tanner's expertise on the SEM was much appreciated.

\section{References}

Akaike, H. (1974). New look at statistical model identification. IEEE Transactions on Automatic Control, 19, 716-723.

Averincev, V. G. (1980). Chauvinelia arctica, sp. n. (Acrocirridae, Polychaeta) from the Canadian Plain. Issledovaniya Fauny Morei, Zoologicheskii Institut Akademii Nauk USSR, 25, 57-62.

Banse, K. (1969). Acrocirridae n. fam. (Polychaeta Sedentaria). Fournal of the Fisheries Research Board of Canada, 26, 2595-2620.

Bleidorn, C., Vogt, L. \& Bartolomaeus, T. (2003a). New insights into polychaete phylogeny (Annelida) inferred from $18 \mathrm{~S}$ rDNA sequences. Molecular Phylogenetics and Evolution, 29, 279-288.

Bleidorn, C., Vogt, L. \& Bartolomaeus, T. (2003b). A contribution to sedentary polychaete phylogeny using $18 \mathrm{~S}$ rRNA sequence data. Fournal of Zoological Systematics and Evolutionary Research, 41, 186-195.

Boore, J. L. \& Brown, W. M. (2000). Mitochondrial genomes of Galathealinum, Helobdella, and Platynereis: sequence and gene arrangement comparisons indicate that Pogonophora is not a phylum and Annelida and Arthropoda are not sister taxa. Molecular Biology and Evolution, 17, 87-106.

Burnette, A. B., Struck, T. H. \& Halanych, K. M. (2005). Holopelagic Poeobius meseres ("Poeobiidae," Annelida) is derived from benthic flabelligerid worms. Biological Bulletin, 208, 213220.

Edgar, R. C. (2004). MUSCLE: multiple sequence alignment with high accuracy and high throughput. Nucleic Acids Research, 32, 1792-1797.

Ehlers, E. (1887). Report on the annelids of the dredging expedition of the U.S. Coast survey steamer Blake. Memoirs of the Museum of Comparative Zoology at Harvard College, 15, VI and 335 pp 360 plates.

Fauchald, K. \& Rouse, G. W. (1997). Polychaete systematics: past and present. Zoologica Scripta, 26, 71-138.

Fauvel, P. (1916). Annélides polychètes pelagiques provenant des campagnes de l'hirondelle et de la Princesse Alice (1885-1910). Resultats des Campagnes Scientifiques, Monaco, 48, 1-152.

Filippova, A. V., Tzetlin, A. B. \& Purschke, G. (2003). Morphology and ultrastructure of the anterior end of Diplocirrus longisetosus Marenzeller, 1890 (Flabelligeridae, Polychaeta, Annelida). Hydrobiologia, 496, 215-223.

Folmer, O., Black, M., Hoeh, R., Lutz, R. \& Vrijenhoek, R. (1994). DNA primers for amplification of mitochondrial cytochrome c oxidase subunit I from metazoan invertebrates. Molecular Marine Biology and Biotechnology, 3, 294-299.

George, J. D. \& Hartmann-Schröder, G. (1985). Polychaetes: British Amphinomida, Spintherida and Eunicida. Keys and notes for the identification of the species. Vol. 32 London: E. J. Brill \& Dr. W. Backhuys.

Gillet, P. (2001). Flabelligena amoureuxi new genus, new species (Polychaeta: Acrocirridae) from Crozet Island (Indian Ocean). Bulletin of Marine Science, 68, 125-131.
Giribet, G., Carranza, S., Riutort, M., Baguña, J. \& Ribera, C. (1999). Internal phylogeny of the Chilopoda (Myriapoda, Arthropoda) using complete $18 \mathrm{~S}$ rDNA and partial $28 \mathrm{~S}$ rDNA sequences. Philosophical Transactions of the Royal Society of London Series B-Biological Sciences, 354, 215-222.

Glasby, C. J. \& Fauchald, K. (1991). Redescription of Helmetophorus rankini Hartman, 1978 (Polychaeta: Helmetophoridae) and its transfer to the Flabelligeridae. Proceedings of the Biological Society of Washington, 104, 684-687.

Gravier, C. (1906). Sur les Annélides Polychètes recueilies par l'Expédition Antarctique française (Aphroditiens, Amphinomiens, Flabelligeriens, Maldaniens, Ampharetiens.). Competes Rendus de l'Académie des Science, Paris., 144, 43-44.

Hartman, O. (1978). Polychaeta from the Weddell Sea quadrant, Antarctica. Antarctic Research, 26, 124-223.

Haswell, W. A. (1892). Observations on the Chloraemidae, with special reference to certain Australian forms. Proceedings of the Linnean Society of New South Wales, Ser, 2, 6.

Heath, H. (1930). A connecting link between the Annelida and the Echiuroidea (Gephyrea armata). Journal of Morphology, 49, 223-249.

Huelsenbeck, J. P. \& Ronquist, F. (2001). MrBayes: Bayesian inference of phylogenetic trees. Bioinformatics, 17, 754-755.

Kirkegaard, J. B. (1982). New records of abyssal benthic polychaetes from the polar sea. Steenstrupia, 8, 253-260.

Kristensen, T. (1997) A taxonomic investigation of the Flabelligeridae in the North Atlantic, with a phylogenetic analysis of the family on a world basis. Thesis, Copenhagen: Zoological Museum, University of Copenhagen, $82 \mathrm{pp}$.

Laubier, L. (1974). Chauvinelia biscayensis gen. sp. nov., un Flabelligeridae (Annélide Polychète sédentaire) aberrant de l'étage abyssal du Golfe de Gascogne. Bulletin de la Société Zoologique de France, 99, 391-399.

Lê, H. L. V., Lecointre, G. \& Perasso, R. (1993). A 28 S rRNA based phylogeny of the Gnathostomes: first steps in the analysis of conflict and congruence with morphologically based cladograms. Molecular Phylogenetics and Evolution, 2, 31-51.

Lenaers, G., Maroteaux, L., Michot, B. \& Herzog, M. (1989). Dinoflagellates in evolution. A molecular phylogenetic analysis of large subunit ribosomal RNA. Fournal of Molecular Evolution, 29, 40-51.

Maddison, D. R. \& Maddison, W. P. (2000). MacClade. Sunderland, MA: Sinauer Associates.

Marenzeller, E. v. (1890). Annulaten des Beringsmeeres. Ann. K. Naturbistor. Hofmus. Wien, 5, 1-18.

McIntosh, W. C. (1885). Report on the Annelida Polychaeta collected by H.M.S. Challenger during the years 1873-1876. Report on the Scientific Results of the Voyage of H.M.S. Challenger during the years $1872-76,12,1-554$.

Medlin, L., Elwood, H. J., Stickel, S. \& Sogin, M. L. (1988). The characterization of enzymatically amplified eukaryotic 16S-like rRNA-coding regions. Gene, 71, 491-499.

Mesnil, F. (1899). La position systématique des Flabelligériens St. Joseph (chlorémiens quatrefages) et des Sternaspiens. Zoologischer Anzeiger, 22, 81-85.

Miller, M. A., Holder, M. T., Vos, R., Midford, P. E., Liebowitz, T., Chan, L., Hoover, P. \& Warnow, T. (2009). The CIPRES Portals. CIPRES. Available via http://www.phylo.org/ 
sub_sections/portal. (Accessed on 4 August, 2009) (Archived by WebCite(r) at http://www.webcitation.org/5imQlJeQa)

Moore, J. P. (1909). Polychaetous annelids from Monterey Bay and San Diego, California. Proceedings of the Academy of Natural Sciences of Philadelphia, 61, 235-295.

Norén, M. \& Jondelius, U. (1999). Phylogeny of the Prolecithophora (Platyhelminthes) inferred from $18 \mathrm{~S}$ rDNA sequences. Cladistics, 15, 103-112.

Orensanz, J. M. (1974). Poliquetos de la provincia biogeografica Argentina. X. Acrocirridae. Neotropica, 20, 113-118.

Osborn, K. J. \& Rouse, G. W. (2008). Multiple origins of pelagicism within Flabelligeridae (Annelida). Molecular Phylogenetics and Evolution, 49, 386-392.

Osborn, K. J., Rouse, G. W., Goffredi, S. K. \& Robison, B. H. (2007). Description and relationships of Chaetopterus pugaporcinus, an unusual pelagic polychaete (Annelida, Chaetopteridae). Biological Bulletin, 212, 40-54.

Osborn, K. J., Haddock, S. H. D., Pleijel, F., Madin, L. P. \& Rouse, G. W. (2009). Deep-sea, swimming worms with luminescent "bombs". Science, 325, 964.

Palumbi, S. R., Martin, A., Romano, S., McMillan, W. O., Stice, L. \& Grabowski, G. (1991). A Simple Fool's Guide to PCR. Honolulu, HI: University of Hawaii Press.

Posada, D. \& Crandall, K. A. (1998). Modeltest: testing the model of DNA substitution. Bioinformatics, 14, 917918.

Posada, D. \& Crandall, K. A. (2001). Selecting the best-fit model of nucleotide substitution. Systematic Biology, 50, 580-601.

Rouse, G. W. \& Fauchald, K. (1997). Cladistics and polychaetes. Zoologica Scripta, 26, 139-204.

Rouse, G. W. \& Pleijel, F. (2001). Polychaetes. Oxford: Oxford University Press.

Rouse, G. W. \& Pleijel, F. (2003). Problems in polychaete systematics. Hydrobiologia, 496, 175-189.

Rouse, G. W., Goffredi, S. K. \& Vrijenhoek, R. C. (2004). Osedax: bone-eating marine worms with dwarf males. Science, 305, 668-671.

Rousset, V., Rouse, G. W., Siddall, M. E., Tillier, A. \& Pleijel, F. (2004). A phylogenetic position of Siboglinidae (Annelida) inferred from $18 \mathrm{~S}$ rRNA, $28 \mathrm{~S}$ rRNA and morphological data. Cladistics, 20, 518-533.

Rousset, V., Siddall, M. E., Rouse, G. W., Pleijel, F. \& Erseus, C. (2007). A molecular phylogeny of Annelids. Cladistics, 23, 41-63.

Salazar-Vallejo, S. I. (2007). Revision of Flabelliderma Hartman, 1969 (Polychaeta: Flabelligerida). Journal of Natural History, 41, 2037-2161.

Salazar-Vallejo, S. I., Gillet, P. \& Carrera-Parra, L. F. (2007). Revision of Chauvinelia, redescriptions of Flabelliseta incrusta, and Helmetophorus rankini, and their recognition as acrocirrids (Polychaeta: Acrocirridae). Fournal of the Marine Biological Association of the United Kingdom, 87, 465-477.

Salazar-Vallejo, S. I., Carrera-Parra, L. F. \& Fauchald, K. (2008). Phylogenetic affinities of the Flabelligeridae (Annelida, Polychaeta). Fournal of Zoological Systematics and Evolutionary Research, 46, 203-215.

Schlieper, C. (1927). Stylarioides plumosus, eine monographische darstellung. Zeitschrift für Morphologie und Ökologie der Tiere, 7, 320-383.
Sjölin, E., Erséus, C. \& Källersjö, M. (2005). Phylogeny of Tubificidae (Annelida, Clitellata) based on mitochondrial and nuclear sequence data. Molecular Phylogenetics and Evolution, 35, 431-441.

Spies, R. B. (1973). The blood system of the flabelligerid polychaete Flabelliderma commensalis (Moore). Fournal of Morphology, 139, 465-490.

Stamatakis, A. (2006). RAxML-VI-HPC: maximum likelihoodbased phylogenetic analyses with thousands of taxa and mixed models. Bioinformatics, 22, 2688-2690.

Struck, T. H., Purschke, G. \& Halanych, K. M. (2006). Phylogeny of Eunicida (Annelida) and exploring data congruence using a partition addition bootstrap alteration (PABA) approach. Systematic Biology, 55, 1-20.

Struck, T. H., Schult, N., Kusen, T., Hickman, E., Bleidorn, C., McHugh, D. \& Halanych, K. M. (2007). Annelid phylogeny and the status of Sipuncula and Echiura. BMC Evolutionary Biology, 7, 1-11.

Swofford, D. L. (2002). PAUP (Phylogenetic Analysis Using Parsimony). Sunderland, MA: Sinauer Associates.

Wilgenbusch, J. C., Warren, D. L. \& Swofford, D. L. (2004). AWTY: a system for graphical exploration of $\mathrm{mcmc}$ convergence in Bayesian phylogenetic inference. Available via http://ceb.csit.fsu.edu/awty, accessed July 2010

Xia, X. H., Xia, Z., Salemi, M., Chen, L. \& Wang, Y. (2003). An index of substitution saturation and its application. Molecular Phylogenetics and Evolution, 26, 1-7.

\section{Supporting Information}

Additional Supporting Information may be found in the online version of this article:

Appendix S1. Matrix of multistate coding scores of morphology. Unknowns are coded with '?' and inapplicable with '-'.

Fig. S1 Photos of various characters. -A. Acrocirrus validus, left lateral view showing four branchiae scars (numbered), the nephridiopore (white arrow), palp (p) and clusters of short interramal papillae (black arrow). - B. Chauvinelia arctica (ZMUC POL-0159) clavate interramal papillae. - C. Chauvinelia biscayensis holotype possible lollipop-shaped interramal papillae. - D. Shining Bomber lollipop interramal papillae. -E. Flabelligera affinis from Edithburgh, Australia with gelatinous sheath removed showing long clavate body papillae. -F. Flabelligera affinis from same collecting event as E, with gelatinous sheath intact. -G. Poeobius meseres showing thick gelatinous sheath (gs) and protruding body papillae (arrow). - - H. Body of Flabelliderma ockeri (right) removed from its sediment encrusted gelatinous sheath (left). - I. Swima sp., dorsal view of head showing palps, medial subulate branchia (sb) and nuchal organ (arrow). - J. Juanita worm, dorsal view of head showing palp scar (p) and branchiae scars (numbered), spiral (spn) and oppositely branched (obn) free-standing nuchal organs. - K. Head of Pherusa plumosa CA showing a palp, branchia, eyes and nephridio- 
pore papillus (arrow). - L. Acrocirrus validus head in dorsal view showing palps, branchiae, eyes, and convoluted nuchal ridges, photo F. Pleijel. - M. Swima bombiviridis ventral view of anterior showing nephridiopores (arrow indicates left nephridiopore), lollipop interramal papillae and subulate branchia. - N. Antero-dorsal view of head of Squidworm showing palps, branchiae, oppositely branched free-standing nuchal organs and nephridiopores (arrow indicates left nephridiopore), photo L. P. Madin.

Fig. S2 Acrocirrid (A-H) and flabelligerid (I-L) chaetae. -A. Shining Bomber distal tip neurochaeta. - B. Juanita worm notochaeta. -C. Tiburon Bomber neurochaeta. -D. Acrocirrus validus notochaetae. -E. Tawi-tawi Bomber notochaeta distal tip. -F. Tawi-tawi Bomber distal element neurochaeta. - G. Squidworm distal portion neurochaeta. -H. Squidworm shaft of neurochaeta. -I. Flota sp. segment joint of notochaetae. - J. Pherusa plumosa CA medial portion notochaeta. -K. Pherusa plumosa CA basal portion notochaetae. -L. Flabelligera mundata neurochaeta.
Scale bars: A $=2 \mu \mathrm{m}, \mathrm{B}-\mathrm{D}, \mathrm{G}$ and $\mathrm{I}=10 \mu \mathrm{m}, \mathrm{E}-\mathrm{F}, \mathrm{H}$ and $\mathrm{J}-\mathrm{L}=40 \mu \mathrm{m}$.

Fig. S3 Strict consensus of 1046189 most parsimonious trees (tree length $=96$ ) from analysis of the morphology matrix.

Fig. S4 Majority rule consensus tree from Bayesian analyses of five concatenated genes. Data were partitioned by each gene and first, second and third codon positions. $C y t B$ third positions were excluded due to saturation. Support is indicated as posterior probabilities from the Bayesian analyses/bootstraps from the parsimony analysis. Asterisks indicate 1.0 or $100 \%$ support respectively; dashes indicate unsupported nodes.

Please note: Wiley-Blackwell are not responsible for the content or functionality of any supporting materials supplied by the authors. Any queries (other than missing material) should be directed to the corresponding author for the article. 
Online-only Supplementary Material for:

\title{
Phylogenetic of Acrocirridae and Flabelligeridae (Annelida, Cirratuliformia)
}

\author{
Karen J. Osborn \\ Scripps Institution of Oceanography, University of California, San Diego, La Jolla, CA \\ 92093-0202, USA. E-mail: karenjosborn@gmail.com \\ Current address: \\ Institute of Marine Science, University of California, Santa Cruz, 1156 High Street, Santa \\ Cruz, CA 95064, USA \\ Greg W. Rouse \\ Scripps Institution of Oceanography, University of California, San Diego, La Jolla, CA \\ 92093-0202, USA. E-mail: grouse@ucsd.edu
}

This pdf includes:

Supplemental Materials and Methods - Character discussion

Supplemental References

Supplemental Figure 1 - Character illustrations

Supplemental Figure 2 - Chaetal characteristics

Supplemental Figure 3 - Morphology tree

Supplemental Figure 4 - Five gene molecular tree

Appendix I - Morphology matrix 


\section{Supplemental Materials and Methods}

Characters were as follows:

1. Retractable head: Head retractable into fold of anterior segments. Flabelligerids can withdraw the anterior portion of their body and head so that they are surrounded by anterior chaetigers (Supplemental Fig. 1E-G, K). No cirratulids have retractile heads, nor does any of the newly discovered swimming species, nor other acrocirrids with a few possible exceptions. Orensanz (1974) suggested that members of Flabelligella (Acrocirridae) may be capable of head retraction, but this needs confirmation. Chauvinelia spp. and $H$. rankini were originally described as having retractable heads (Laubier 1974; Hartman 1978) but this may not be the case. When describing Chauvinelia arctica, Averincev (1980) noted that the expanded anterior part of the body enveloping the preceding segments might have been caused by contraction of the worm during fixation. However, Laubier (1974) noted that prior to fixation, the prostomium of his $C$. biscayensis specimens was hidden inside the cephalic hood and that he was able to evert it with pressure on the anterior body. Salazar-Vallejo et al. (2008) suggested that Chauvinelia spp., H. rankini and possibly Buskiella (synonymized with Flota SalazarVallejo \& Zhadan 2007, but maintained as a separate genus here) have a non-retractile anterior but that some anterior chaetigers do form a cephalic hood (see next character). Salazar-Vallejo et al.'s (2008) explanation being that these segments are hypertrophied enlarged due to enlargement of individual cells - and thus expands over parts of the head. This remains to be confirmed by histological examination. No further explanation was given regarding the retractability of anterior segments (Salazar-Vallejo et al. 2008). It is unclear if this expansion of non-retractile segments to form a cephalic hood and partially covering the head occurs in life, or just in preserved specimens.

The flabelligerid Flota sp. is most often observed in situ with its head retracted into the anterior portion of its body (K. J. Osborn pers. obs.). Thus the retraction of the head in Flota sp. is not a preservation artifact; the worms typically carry the head inverted and can evert it. Relaxation of living specimens does not consistently result in eversion of the head. 
Many gelatinous worms wither or contract dramatically when injured or fixed. This occurs as soon as the gelatinous sheath or body is damaged and was directly and repeatedly observed by KJO in P. meseres and Flota species. The nature of the thin, amorphous membrane surrounding the body of both Chauvinelia species (Fig. 1C) indicates that all specimens are considerably shrunken in a way similar to that seen in Flota species. Thus Chauvinelia spp. may well have thick gelatinous sheathes within which the bodies contract during handling and fixation. This contraction could easily account for the infolding of the anterior region in the specimens of Chauvinelia and thus make it impossible to determine if the head is actually retractable until live specimens can be observed. On the other hand, the smooth and featureless nature of the posterior portion of the infolded region, together with the possession of a cephalic hood, leaves the retractability of the anterior end in question. Based on KJO's observations of gelatinous animals and the rest of Acrocirridae lacking retractable heads, we follow the scoring of Salazar-Vallejo et al. (2008) and consider the head of Chauvinelia arctica non-retractile.

Helmetophorus rankini specimens lack the large, loose membrane indicative of both a thick gelatinous sheath and significant contraction of the body away from that sheath during injury or fixation (Fig. 1I). Thus this species was assumed to have only a thin gelatinous sheath, if any, and an unknown amount of contraction. All H. rankini heads were covered a similar amount by the cephalic hood, leaving the oral tube and prostomium exposed, possibly suggesting that the head is not retractile. Therefore, with respect to $H$. rankini we follow Salazar-Vallejo et al.'s (2008) scoring of this species as "head non-retractile".

2. Cephalic hood. Flabelligeridae posses a cephalic hood into which the head is pulled when the head is retracted. In flabelligerids this hood has a smooth, featureless anterior portion that folds into itself leaving the chaetae of the cephalic crown, or first chaetiger, at the anterior-most margin when the head is inverted. The exterior portion of the hood (the part exposed when the head is fully inverted) has a different texture than the interior portion of the hood. Members of Cirratulidae, Macrochaeta, Acrocirrus, Flabelliseta and Flabelligena lack any structures that could be construed as cephalic hoods. The nature of a cephalic hood is poorly noted or illustrated for Flabelligella by Orensanz (1974) and is scored as absent here. 
Helmetophorus rankini and Chauvinelia spp. have anterior achaetous segments that fold over at least some portion of the peristomium and prostomium in fixed specimens and this feature was called a cephalic hood by previous authors (Laubier 1974; Hartman 1978, Glasby \& Fauchald 1991; Salazar-Vallejo et al. 2007). As outlined above, Salazar-Vallejo et al. (2008) suggested that one or two achaetous anterior segments of Chauvinelia spp. and H. rankini have enlarged, forming a non-retractile cephalic hood. Both Chauvinelia spp. and H. rankini have substantial anterior achaetous regions that are as wide or wider than the head and near the width of the widest part of the body. This region appears to be uniform for at least half its length and does fold over anterior segments and parts of the head, but this folding may be a preservation artifact in at least Chauvinelia spp., as discussed above. Averincev (1980) described the cephalic hood of Chauvinelia as an expanded region that lacks morphological features, is posterior to the achaetous segments supporting the branchiae, and is equal in length to the region supporting branchiae. In Helmetophorus the cephalic hood was described as "helmet-like dorsally, low and collar-like ventrally, extending anteriorly to the branchial membrane" by Glasby \& Fauchald (1991) and later as "dorsally projecting and ventrally reduced" by Salazar-Vallejo et al. (2007). The dorsally projecting shape of the hood is consistent between specimens of Helmetophorus, making it a feature distinct from other known acrocirrids. Whether the observed structures are due to contraction during fixation or are actually a feature of the animals remains in question for at least Chauvinelia spp. and is here scored as "present" based on historical precedent and the lack of contradictory evidence. Helmetophorus rankini certainly has some form of cephalic hood (or "helmet" as the name indicates) based on the consistency of the asymmetrical, dorsally projecting shape of this structure in the types.

The achaetous regions of Swima bombiviridis and "Shining" and "Tawi-tawi" Bombers (Fig. 1A, D) are much shorter than those observed in Chauvinelia spp. and $H$. rankini and support prominent features such as the pair of nephridiopore papillae and four pairs of elliptical branchiae or, when those are lost (as is often the case), prominent circular scars (Suppl. Fig. 1I, M). The anterior achaetous region of "Horned" and "Tiburon" Bombers (Fig. 1F, G), although similar in relative length to those of Chauvinelia spp. and H. rankini, are muscular, narrow and never folded over themselves 
as is seen in all known specimens of Chauvinelia and H. rankini. Additionally, the large (length more than half width widest part of the body) elliptical branchiae are prominent throughout the achaetous regions on Horned and Tiburon Bombers. "Juanita" worm possesses a long, broad and relatively featureless achaetous region (Fig. 1H). This achaetous region of Juanita worm is made up of two elongate segments (indicated internally by septa and externally by two rows of clavate papillae in the location parapodia would be expected) just posterior to the branchial membrane and anterior to the first chaetiger. The second, or posterior-most, segment of this region supports the anterior-most pair of gonopores. The body wall in the region, as in the rest of the body, is muscular, lacking a thick gelatinous sheath, and does not extend over anterior segments or the head (Suppl. Fig. 1J). Thus, none of the recently discovered swimming acrocirrids have a cephalic hood.

\section{Achaetous anterior segments. All cirratulids (except Ctenodrilus serratus serratus} (Schmidt, 1857)) available for this analysis were scored as possessing a single achaetous anterior segment based on the discussion by Rouse \& Pleijel (2001), though the issue is needs further study of the peristomium and the unusual position of the palps in several cirratulids. Acrocirrids have various numbers of achaetous anterior segments. The nature of flabelligerid branchiae and the associated achaetous segments is unknown (see Rouse $\&$ Pleijel 2001 and discussion below).

4. Cephalic cage. This can be defined as the chaetae of first chaetiger being at least one third longer than those of the midbody. The anterior-most chaetigers of flabelligerids such as Pherusa spp., Flabelligera spp., and Piromis spp. have such a cephalic cage. Cirratulidae and Acrocirridae lack any such chaetae, as do flabelligerids such as Brada spp., P. meseres, Flota spp., and some Diplocirrus species.

5. Externally obvious segment margins on majority of body. The segments are externally obvious on all cirratulids and on some flabelligerids and acrocirrids. The thickness of the cuticle and of gelatinous sheath, as well as the amount of foreign particles adhered to the gelatinous sheath all impact but do not necessarily determine this state. For example, Piromis spp. have thick gelatinous sheathes and a thick layer of adhered particles yet the segment margins are still distinct on the outer surfaces of the animals. Additionally, although a thick gelatinous sheath is present in S. bombiviridis, Shining and Tawi-tawi 
Bombers, segment margins are externally obvious (Fig. 1A, B, D). On the other hand, species such as $P$. meseres and some Flabelliderma spp. have a thick gelatinous sheathes and indistinct segment margins.

6. Papillae. Acrocirrids and flabelligerids have small epidermal papillae on at least on some parts of their bodies. Cirratulids lack papillae. Epidermal papillae extend from the epidermis through the gelatinous sheath (when it is present), sometimes extending beyond the outer surface of the sheath, as in P. meseres (Suppl. Fig. 1G) and $S$. bombiviridis, Shining and Tawi-tawi Bombers. The papillae can be numerous and closely cover the body as in most Flabelligera (Suppl. Fig. 1E) and Flabelligena spp. or can be sparse and found only on certain parts of the body such as around the chaetae as in Acrocirrus validus (Suppl. Fig. 1A).

7. Body papillae. Papillae range from short to long. Longer than wide papillae always have a slightly bulbous distal tip (clavate, Fig. 1B, E) and seem to be associated with thick gelatinous sheaths. Thus this character may be linked to the thickness of the gelatinous sheath since species with long body papillae have thick gelatinous sheaths. The nature of the body papillae has been used extensively in the past (Salazar-Vallejo 2007; Salazar-Vallejo et al. 2008).

8. Interramal papillae. Some taxa have a concentration of papillae between the rami of the parapodia (Suppl. Fig. 1A-D). Often these papillae are arranged in a row. The papillae can be short (similar width and length; Fig 3A), or long with a narrow stalk and slightly bulbous tip (clavate; Suppl. Fig. 1B). Lollipop and balloon-shaped papillae are unusual and distinct from clavate papillae. Lollipop papillae have a spherical tip and a narrow (less than one quarter the width of the spherical tip) stiff stalk; the slightly "onion-dome"-shaped tip is solid and the surface appears granular as in Chauvinelia biscayensis (Suppl. Fig. 1C, but not C. arctica Suppl. Fig. 1B) and Swima (e.g. Suppl.

Fig. 1D). Balloon-shaped papillae are known only from F. incrusta and have long threadlike stalks and hollow, balloon-like spherical sacs at the distal tips. Hartman (1978) considered $F$. incrusta's balloon-shaped papillae to be modified notochaetae but SalazarVallejo et al. (2007) established their identity as papillae.

9. Sediment adhered to body. Many flabelligerids adhere particles to their gelatinous sheath, for example Flabelliderma spp. (Suppl. Fig. 1H), Brada spp., Pherusa spp., 
Piromis spp. and Ilyphagus species. Acrocirrids belonging to Macrochaeta, Flabelligena, and Flabelligella adhere fine particles and F. incrusta adheres larger sediment particles to its cuticle. Cirratulids do not adhere particles to their bodies, nor do the acrocirrids $S$. bombiviridis, Shining and Tawi-tawi Bombers, H. rankini, Chauvinelia spp., nor the flabelligerids Flota spp. and P. meseres.

10. Gelatinous sheath. All Flabelligeridae (Salazar-Vallejo 2007 as mucus-sheath or tunic) and many Acrocirridae possess a gelatinous sheath covering the epidermis. The gelatinous sheath can be nearly distinct from the body as in Flabelligera affinis Sars, 1829 (Suppl. Fig. 1F), tough and capsule-like as in Piromis spp. or Flabelliderma spp. (Suppl. Fig. 1H), or an integral part of the body like in Flota spp., P. meseres (Suppl. Fig. 1G) S. bombiviridis and Shining and Tawi-tawi Bombers (Fig. 1A). The gelatinous sheath can be difficult to observe when it is thin as in Flabelligera commensalis Moore, 1909, "Squidworm" and Horned and Tiburon Bombers. Cirratulids lack a gelatinous sheath. In all Cirratuliformia that have a gelatinous sheath the body papillae project from the body through the gelatinous sheath (Suppl. Fig. 1G) and may be responsible for secreting it, although this requires further investigation.

11. Prostomium shape. The prostomium of cirratulids is terminal and cone-shaped while it is dorsally located and plate-like in flabelligerids (Suppl. Fig. 1K) and acrocirrids (Suppl. Fig. 1I, J, L, N). Flabelligerid prostomiums differ from that of acrocirrids in that the nuchal organs project posteriorly between the branchial membranes (see discussion for characters 14 and 15 below). The margins of the prostomium are difficult to define as evidenced by the various definitions used in the past (Spies 1975; Hutchings 2000; Salazar-Vallejo et al. 2008) but are here assumed to consist of the tissue immediately posterior and dorsal to the palps, supporting the nuchal organs, and extending to the anterior margin of the main or first segmental branchiae.

12. Grooved palps. Many polychaete groups have grooved palps, for example Spionidae have a single pair on the peristomium and Terebellidae have multiple pairs on the prostomium. A single pair is found in Acrocirridae (Suppl. Fig. 1I, L, N), Flabelligeridae (Suppl. Fig. 1K), and some Cirratulidae such as Dodecaceria. Cirratulids such as Cirratulus spp. and Cirriformia spp. have multiple peristomial palps (though derived from an initial single pair, Rouse \& Pleijel 2001). Grooved palps are lacking in C. s. 
serratus. Flabelligerid and acrocirrid palps are considered here to be peristomial, but this needs confirmation by development studies.

13. Eyes. Eyes are present and often variable on flabelligerids (Suppl. Fig. 1K) and acrocirrids (Suppl. Fig. 1L). All cirratulids considered here have eyes except $C$. $s$. serratus. Poeobius meseres, Flota spp., all recently discovered swimming acrocirrids, Chauvinelia spp. and $H$. rankini all lack eyes.

14 and 15. Nuchal organs. Nuchal organs are considered to be chemosensory organs consisting of a cluster of ciliated cells on the prostomium. Cirratulids have simple nuchal organs consisting of a pit. Spies (1975) considered only the ciliated pit next to the palps of flabelligerids the nuchal organs but not the two pairs of ciliary tracts that extend out from them along the prostomial ridge, thus contradicting Orrhage (1966) and Schliepers' (1927) interpretations that included the ciliary tracts running parallel to the body axis. We have here considered the ciliary tracts connected to the pits and running along the prostomial ridge (extends dorsally between the branchial membranes) as the nuchal organs of flabelligerids. Acrocirrids have variable nuchal structures ranging from short, relatively straight ciliated ridges as in S. bombiviridis and Shining and Tawi-tawi Bombers (Suppl. Fig. 1I arrow) to long, convoluted ridges with many $180^{\circ}$ bends as seen in A. validus (Suppl. Fig. 1L), or a combination of a long ridge with the ciliated tracts extending onto free-standing structures such as the oppositely branched appendages and spiral structures seen in Juanita worm (Suppl. Fig. 1J). Incidentally, the portion of the head across which the ciliary tracts or ridges extend is here considered the extent of the prostomium until developmental studies can provide further information.

16. Head branchiae. Unusual structures are found on the prostomium of S. bombiviridis (Suppl. Fig. 1I), Shining, Tawi-tawi, Horned and Tiburon Bombers (Figs 1B, D, F, G), Chauvinelia spp. and $H$. rankini that are here considered branchiae, based on the presence of large afferent and efferent vessels within the structures. This follows previous authors (Laubier 1974; Averincev 1980; Glasby \& Fauchald 1991; Salazar-Vallejo et al. 2007). These structures have broad bases and taper evenly to their tips (Suppl. Fig. 1I). Unlike typical acrocirrid palps and branchiae these are not easily lost and leave a ragged scar if they are. These branchiae occur in one or more rows and the bases are surrounded by the convoluted, ciliated ridges of the nuchal organs of Chauvinelia spp., H. rankini, and 
Horned and Tiburon Bombers (Fig. 1G). The identity of these structures puzzled Hartman (1978) when she originally allied $H$. rankini with Hesionidae, suggesting they were anterior dorsal cirri. The location of these structures surrounded by the nuchal organs would suggest that they are prostomial, but they are always medial to the nuchal organs instead of completely enclosed by the ciliated ridges. Hence it may be that they are segmental in origin and have migrated to their antero-dorsal position. Glasby \& Fauchald (1991) concluded the two types of branchiae seen in $H$. rankini were not homologous because they arose from different areas. This type of branchia is not found in Cirratulidae, Flabelligeridae, previously known acrocirrids other than Chauvinelia spp. and $H$. rankini, nor Squidworm and Juanita worm.

17. Main branchiae. Branchial filaments show great variety within the groups considered here. Ctenodrilus s. serratus lacks branchial filaments and Dodecaceria spp. have four pairs restricted to anterior segments, though most cirratulids have numerous pairs of long digitiform branchiae along the body. Flabelligerids have various forms of branchiae that are typically concentrated just behind the prostomium on what has often been referred to as the branchial membrane. The branchial membrane can be flat on the body as in Flabelligera spp., Flabelliderma spp., Pherusa spp. and Diplocirrus spp., or it can be a projecting structure or structures as in members of Coppingeria sp., Diversibranchus nicolaji Buzhinskaja, 1993 and Piromis species. The branchial membranes may support attachment of four to over 80 pairs of branchial filaments. Acrocirrid branchial filaments are found in pairs on two to usually four anterior segments. In S. bombiviridis, Shining, Tawi-tawi, Horned, and Tiburon Bombers and H. rankini, these branchiae are short, elliptical bulbs (Fig. 1A, F, G) (see character 19).

18. Main branchiae (number of pairs). Among cirratulids and flabelligerids the number of branchial pairs varies widely. Acrocirrids have four pairs with the possible exception of Flabelligella spp. that is reported to have only two pairs (Kolmer 1985) and Chauvinelia spp. that were reported to have only three pairs (0-3 in C. arctica, Averincev 1980). However, the branchiae referred to by Averincev are the same here referred to as "head branchiae" and we suggest the indistinct swellings on the achaetous segments are branchial scars based on similar structures observed in S. bombiviridis, Shining, Tawitawi, Horned and Tiburon Bombers and H. rankini. Only two pairs of these scars were 
drawn (Averincev 1980), thus they are scored here as having just two pairs but it is possible with the contraction, distortion and the poor condition of the specimens that others are present but indistinguishable. Additionally, the other acrocirrids scored as having just two pairs of main branchiae (F. incrusta, Flabelligella sp. and H. rankini) may be the result of missing information as well, since all accounts are unconfirmed or incomplete with respect to this character.

19. Main branchiae (shape). The main branchiae of cirratulids are long and digitiform. Branchial filaments in most flabelligerids are also digitiform (Suppl. Figs 1G, K) with the exception of the unusual forms found in D. nicolaji and Flota species. Acrocirrids such as A. validus (Suppl. Fig. 2L), Macrochaeta spp., Flabelligella spp., Flabelligena spp., and F. incrusta have digitiform branchial filaments like those of cirratulids, however some acrocirrids have an unusual form. The unusual branchial form was first found in $H$. rankini by Glasby \& Fauchald (1991) who referred to them as "foliose". This branchial form is short, being less than twice as long as wide, or elliptical. These elliptical branchiae are also found in S. bombiviridis, Shining, Tawi-tawi, Horned and Tiburon Bombers. These branchiae are the structures autotomized by S. bombiviridis and Shining Bomber that bioluminesce brilliant green. Digitiform branchiae that were shorter than normal have also been observed in a possibly undescribed Flabelligena species (Osborn et al. 2009 suppl. Fig. S2D).

20. Nephridiopores as papillae. A pair of large anterior nephridia is found in all adequately investigated Cirratuliformia and the nephridiopores for these nephridia are likewise found in anterior segments. In cirratulids and some flabelligerids these nephridiopores are simple pores. However, other flabelligerids, such as Pherusa plumosa CA and Diplocirrus longisetosus ((Marenzeller, 1890) Filippova et al. 2003), and several acrocirrids, such as Flabelligena spp., Flabelligella spp. and some species of Acrocirrus and Macrochaeta, have projecting papillae as the nephridiopores. Banse (1969) was the first to suggest that these structures may be nephridiopores and their presence has been noted or illustrated by other authors (Orensanz 1974; Rouse \& Pleijel 2001; Kolmer 1985; Kudenov 1976; Santos \& Silva 1993; Aguirrezabalaga \& Ceberio 2006). 21. Nephridiopores (location). The precise location of the nephridiopore is unknown in cirratulids other than C. s. serratus, where it is found on the peristomium (Rouse \& 
Pleijel 2001). In all recently discovered swimming acrocirrids the large anterior nephridia connect to the papillae on segment 2, confirming Banse's suggestion (1969). In flabelligerids such as P. plumosa CA, D. longisetosus and Flabelligera spp. the nephridiopore is on the branchial membrane. In those flabelligerids with four pairs of branchiae, the nephridiopore papillae are consistently located at the bases of the second pair of branchiae (the most lateral branchia was here considered the first) suggesting that the branchiae of flabelligerids are homologous to the segmental branchiae of acrocirrids. 22. Parapodia distinct from body wall. Parapodia are simple structures when present in the groups considered here. Cirratulids generally have no protruding tissue forming parapodia and those of flabelligerids and acrocirrids, when present, are broad, smooth projections.

23. Uniramous anterior chaetigers. A few taxa considered here have one or more uniramous anterior chaetigers, for example Acrocirrus spp., Macrochaeta spp., Flabelligena spp. and H. rankini have at least one pair of parapodia lacking neurochaetae, $F$. incrusta lacks notochaetae throughout, and all other taxa have only biramous anterior chaetigers.

24. Chaetae. Cirratulid chaetae are smooth, while flabelligerid chaetae are unusual in having distinctive cross-barring, referred to as barred (Rouse \& Pleijel 2001), or multiarticulate (Salazar-Vallejo et al. 2007). Salazar-Vallejo et al. (2008) argued that this feature distinguished flabelligerids from other taxa because the articulations are found along the length of each chaeta (articulations may be indistinct basally) and are created by many cone shaped layers stacked on top of each other with complete internal septa running through the external hyaline cortex. With scanning electron microscopy of airdried chaetae, this is seen as a plate around which the exterior collapses in Flota sp. (Fig. 3I). In P. plumosa CA (Fig. 3J-K) and Flabelligera mundata Gravier, 1906 (Suppl. Fig. 2L) scanning electron microscopy shows the internal layers and external hyaline layer as described by Salazar-Vallejo et al. (2008). Acrocirrids on the other hand have what are typically referred to as spinous chaetae, described by Salazar-Vallejo et al. (2007) as a dehiscent crust of successive rings of tiny denticles over a smooth, non-annulated core. While this appears to be the case under light microscopy, scanning electron microscopy reveals a slightly different arrangement. The exterior is not smooth as in flabelligerids; 
there are always fine spines or fibers on the exterior of the chaetae (Suppl. Figs 2A, D), and these spines are typically most pronounced distally (Suppl. Fig. 2B). In some species the rings of denticles appear to be cones of various lengths whose edges exhibit varying degrees of raggedness (Suppl. Figs 2A-C, F-G). In others there are long layers ending distally in ragged rows (Suppl. Figs 2E, H), or simply denticles randomly dispersed over the surface (Suppl. Fig. 2D). The difference between flabelligerid and acrocirrid chaetae seems to be that flabelligerids appear to have internal segments as stacked cylinders and these are covered by a thin, smooth, outer layer that never has denticles on the surface. Acrocirrid chaetae on the other hand, may have smooth shafts (Suppl. Fig. 2E) but always have denticles on at least the distal tips (Suppl. Figs 2A-H). In some acrocirrids the whorls of spines seem to be the edges of cup-shaped segments of unknown depth through the chaetae (Suppl. Figs 2B-C, F-G). The cups may form an outer sheath as suggested by Salazar-Vallejo et al. (2007) or penetrate through the shaft; no evidence was obtained to suggest the cups are only an outer sheath.

25. Compound chaetae. Cirratulidae have only simple (lacking a joint) chaetae. Flabelligerids have only simple capillaries in their notopodia and capillaries, hooks, and compound or pseudocompound hooks in their neuropodia. Acrocirrid notochaetae are capillary and their stout neurochaetae can be simple, pseudocompound or compound. The term pseudocompound has been inconsistently applied to intermediates between simple and compound chaetae, typically defined as having a fold instead of a true hinge, having an incomplete socket, or having a double ligament restricting the free movement of the second element within the socket (Merz \& Woodin 2006). The stout chaetae found in members of Acrocirrus, Macrochaeta, Flabelligena, Flabelligella, Flabelliderma, Diplocirrus, Piromis, Therochaeta, Flabelligera (Suppl. Fig. 2L) and in Juanita worm have been referred to as pseudocompound because of the rigidity of the joint and incomplete socket, however these are not differentiated for this project from the truly compound chaetae (Suppl. Fig. 2F) found in Chauvinelia spp., Tawi-tawi (Suppl. Fig. 2F), Horned and Tiburon Bombers.

26. Broad, flattened chaetae. Tawi-tawi Bomber and Squidworm have broad, flattened chaetae (Suppl. Figs 2E-H). This feature is unique among the taxa considered here 
although several flabelligerids and acrocirrids have chaetae whose shafts are not cylindrical (Suppl. Fig. 2L).

27. Neurochaetae (second element). The distal element of the compound chaetae when present can be straight (Suppl. Fig. 2F), slightly curved along its length, or distinctly hooked at the tip (Suppl. Fig. 2L).

28. Discrete gonads in few segments. Cirratulids produce gametes in multiple abdominal segments, as do previously studied acrocirrids (Banse 1969). Flabelligerids generally have gonads in a few anterior segments (e.g. Pherusa spp. Schlieper 1927 and Amor 1994; F. commensalis Spies 1977; P. meseres Robbins 1965; Flota flabelligera Hartman 1967). All recently discovered swimming acrocirrids have gonads in three or fewer anterior segments (Fig. 1A).

29. Like the majority of polychaetes (Rouse \& Fauchald 1997), cirratulid guts are straight, as are those of members of Acrocirrus, Macrochaeta and Flabelligena. The guts of all recently discovered swimming acrocirrids have at least one loop (Fig. 1A-B), similar to all examined flabelligerids (Fig. 2G). 


\section{Supplemental References}

Aguirrezabalaga, F. \& Ceberio, A. (2006). Flabelligena gascognensis sp. nov.

(Polychaeta: Acrocirridae), a new species from the Cape Breton Canyon (Bay of Biscay, NE Atlantic). Scientia Marina, 70S1, 141-147.

Amor, A. (1994). Gametes, fertilization and development of Pherusa sp., an endolithic worm (Polychaeta, Flabelligeridae). Mémoires du Muséum National D'Histoire Naturelle, 162, 612.

Buzhinskaja, G. (1993). Diversibranchus nicolaji gen. and sp. n. from the Sea of Japan with unique branchial structure (Polychaeta: Flabelligeridae). Zoological Institute, St. Petersburg, 2, 229-231.

Fauchald, K. (1977). The polychaete worms. Definitions and keys to the orders, families and genera. Natural History Museum of Los Angeles County Science Series, 28, 1188.

Gillandt, L. (1979). Zur systematik, autokologie und biologie der polychaeten des Helgolander Felslitorals. Mitteilungen aus dem Hamburgischen zoologischen Museum und Institut, 76, $19-73$.

Grube, A. E. (1873). Die familie der cirratuliden. Jahresb Schl Gesellsch Vaterländ Cultur Breslau, 50, 59-66.

Hartman, O. (1965). Deep-water benthic polychaetous annelids off New England to Bermuda and other North Atlantic areas. Occasional Papers of the Allan Hancock Foundation, 28, $1-378$.

Hartman, O. (1967). Polychaetous annelids collected by the USNS Eltanin and Staten Island cruises, chiefly from Antarctic seas. Allan Hancock Monographs in Marine Biology. 2, 1-387.

Hartman, O. (1969). Atlas of the sedentariate polychaetous annelids from California. Los Angeles: Allan Hancock Foundation, University of Southern California.

Hutchings, P. 2000. Family Flabelligeridae. In P. L. Beesley, G. J. B. Ross \& C. J. Glasby (Eds) Polychaetes and Allies: The southern sythesis. Fauna of Australia. 4A. Polychaeta, Myzostomida, Pogonophora, Echiura, Sipuncula. (pp 215-218). Melbourne: CSIRO Publishing. 
Johnson, H. P. (1901). The Polychaeta of the Puget Sound region. Proceedings of the Boston Society for Natural History, 29, 381-437.

Kinberg, J. G. H. (1866). Annulata nova. Öfversigt af Königlich Vetenskapsakademiens förhandlingar, Stockholm, 23, 97-103.

Kolmer, D. W. 1985. Acrocirridae (Annelides Polychetes) abyssaux: Golfe de Gascogne et Mediterranee. In L. Laubier \& C. Monniot (Eds) Peuplements profonds $d u$ Golfe de Gascogne: Campagnes biogas pp. 355-364). Brest: IFREMER.

Kudenov, J. D. (1976). Polychaeta from southeastern Australia 1. Acrocirridae Banse, 1969, from Victoria and New South Wales. Records of the Australian Museum, 30, 137-151.

Light, W. J. (1978). Reexamination of the species referred to the genus Flabelliderma Hartman (Polychaeta: Flabelligeridae and Acrocirridae). Proceedings of the Biological Society of Washington, 91, 681-690.

Malmgren, A. J. (1867). Annulata Polychaeta Spetsbergiae, Groenlandiae, Islandiae et Scandinaviae hactenus cognita. Öfversigt af Königlich Vetenskapsakademiens förhandlingar, Stockholm, 24, 127-235.

Marenzeller, E. v. (1879). Südjapanische anneliden. I. Amphinomea, Aphroditea, Lycoridea, Phyllodocea, Hesionea, Syllidea, Eunicea, Glycerea, Sternaspidea, Chaetopterea, Cirratulea, Amphictenea. Denkschriften der Mathematisch-naturwissenschaftlichen classe der Kaiserliche Akademie der Wissenschaften, Wien, 41, 109-154.

Merz, R. A. \& Woodin, S. A. (2006). Polychaete chaetae: Function, fossils, and phylogeny. Integrative and Comparative Biology, 46, 481-496.

Montagu, G. (1808). New and rare animals found on the south coast of Devonshire. Transactions of the Linnaean Society of London, 9, 108-111.

Müller, O. F. (1776). Zoologicae Danicae Prodromus, seu Animalium Daniae et Norvegiae indigenarum characteres, nomina et synonyma imprimis popularium. Havniae [Copenhagen]: Hallageriis.

Orrhage, L. (1966). Über die anatomie des zentralen nervensystemes der sedentären polychaeten. Arkiv för Zoologi, 19, 99-133.

Örsted, A. S. (1843). Annulatorum danicorum conspectus. Fasc. 1 Maricolae. Hafniae: Librariae Wahlianae.

Rathke, H. (1843). Beiträge zur Fauna Norwegens. Nova Acta der Kaiserlichen Leopold-Carolin 
Deutschen Akademie der Naturforscher, Halle, 20, 1-264.

Robbins, D. E. (1965). The biology and morphology of the pelagic annelid Poeobius meseres Heath. Journal of Zoology (London). 146, 197-212.

Saint-Joseph, A. d. (1894). Les Annélides polychètes des côtes de Dinard. Troisième partie. Annales des sciences naturelles, Paris, 17, 1-395.

Salazar-Vallejo, S. I. \& Zhadan, A. E. (2007). Revision of Buskiella McIntosh, 1885

(including Flota Hartman, 1967), and description of its trifid organ (Polychaeta:

Flotidae). Invertebrate Zoology, 4, 65-82.

Santos, P. J. P. d. \& Silva, V. M. A. P. d. (1993). Macrochaeta westheidei n. sp., first record of Acrocirridae for the Brazilian coast (Annelida, Polychaeta). Nerítica, 7, $7-12$.

Sars, M. (1829). Bidrag til Soedyrenes Naturhistorie. Bergen: Chr. Dahl.

Sars, M. (1835). Beskrivelser og Iagttagelser over nogle moerkelige eller nye i Havet ved den Bergenske Kyst levende Dyr af Polypernes, Acalephernes, Radiaternes, Annelidernes og Molluskernes classer, med en kort Oversigt over de hidtil af Forfatteren sammesteds fundne Arter og deres Forekommen. Bergen: Thorstein Hallegers Forlag hos Chr. Dahl.

Schmidt, O. (1857). Zur Kenntnis der Turbellaria, Rhabdocoela und einiger anderer Wuermer des Mittelmeeres. Sitzungsberichte der Kaiserliche Akademie der Wissenschaften, Wien, Mathematisch-Naturwissenschaftliche Klasse, 23, 347-366, plates 341-345.

Spies, R. B. (1975). Structure and function of the head in flabelligerid polychaetes. Journal of Morphology, 147, 187-207.

Spies, R. B. (1977). Reproduction and larval development of Flabelliderma commensalis (Moore). In D. J. Reish \& K. Fauchald (Eds) Essays on polychaetous annelids in memory of Dr. Olga Hartman pp. 323-345). Los Angeles: The Allan Hancock Foundation, University of Southern California. 

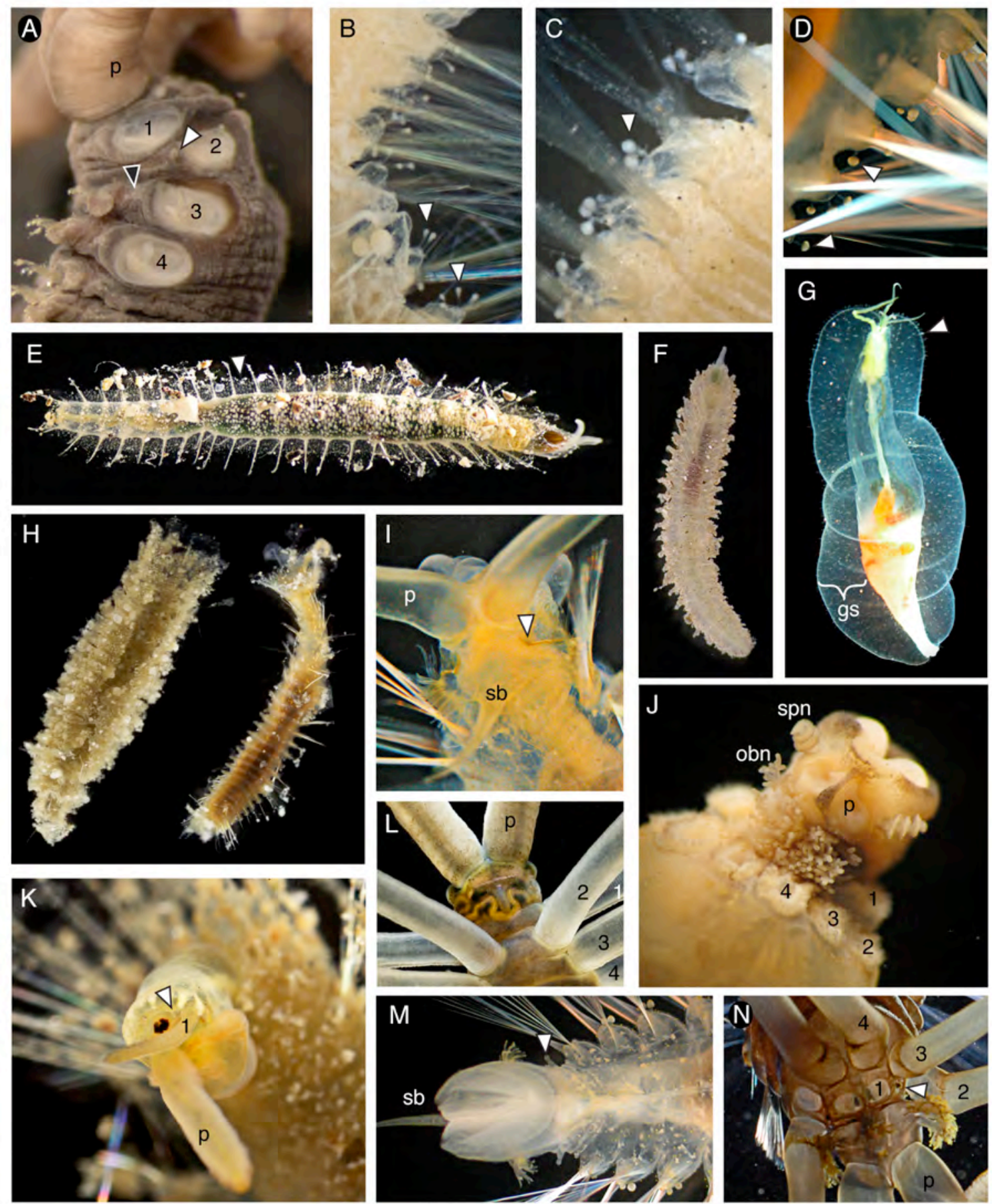

Supplemental Figure 1. Photos of various characters. A. Acrocirrus validus, left lateral view showing four branchiae scars (numbered), the nephridiopore (white arrow), palp (p) and clusters of short interramal papillae (black arrow). B. Chauvinelia arctica (ZMUC POL-0159) clavate interramal papillae. C. Chauvinelia biscayensis holotype possible lollipop-shaped interramal papillae. D. Shining Bomber lollipop interramal papillae. E. Flabelligera affinis from Edithburgh, Australia with gelatinous sheath removed showing long clavate body papillae. F. Flabelligera affinis from same collecting event, with gelatinous sheath intact. G. Poeobius meseres showing thick gelatinous sheath (gs) and 
protruding body papillae (arrow). H. Body of Flabelliderma ockeri (right) removed from its sediment encrusted gelatinous sheath (left). I. Swima sp., dorsal view of head showing palps, medial subulate branchia (sb) and nuchal organ (arrow). J. Juanita worm, dorsal view of head showing palp scar (p) and branchiae scars (numbered), spiral (spn) and oppositely branched (obn) free-standing nuchal organs. K. Head of Pherusa plumosa CA showing a palp, branchia, eyes and nephridiopore papillus (arrow). L. Acrocirrus validus head in dorsal view showing palps, branchiae, eyes, and convoluted nuchal ridges, photo F. Pleijel. M. Swima bombiviridis ventral view of anterior showing nephridiopores (arrow indicates left nephridiopore), lollipop interramal papillae and subulate branchia. $\mathrm{N}$. Antero-dorsal view of head of Squidworm showing palps, branchiae, oppositely branched free-standing nuchal organs and nephridiopores (arrow indicates left nephridiopore), photo L.P. Madin. 

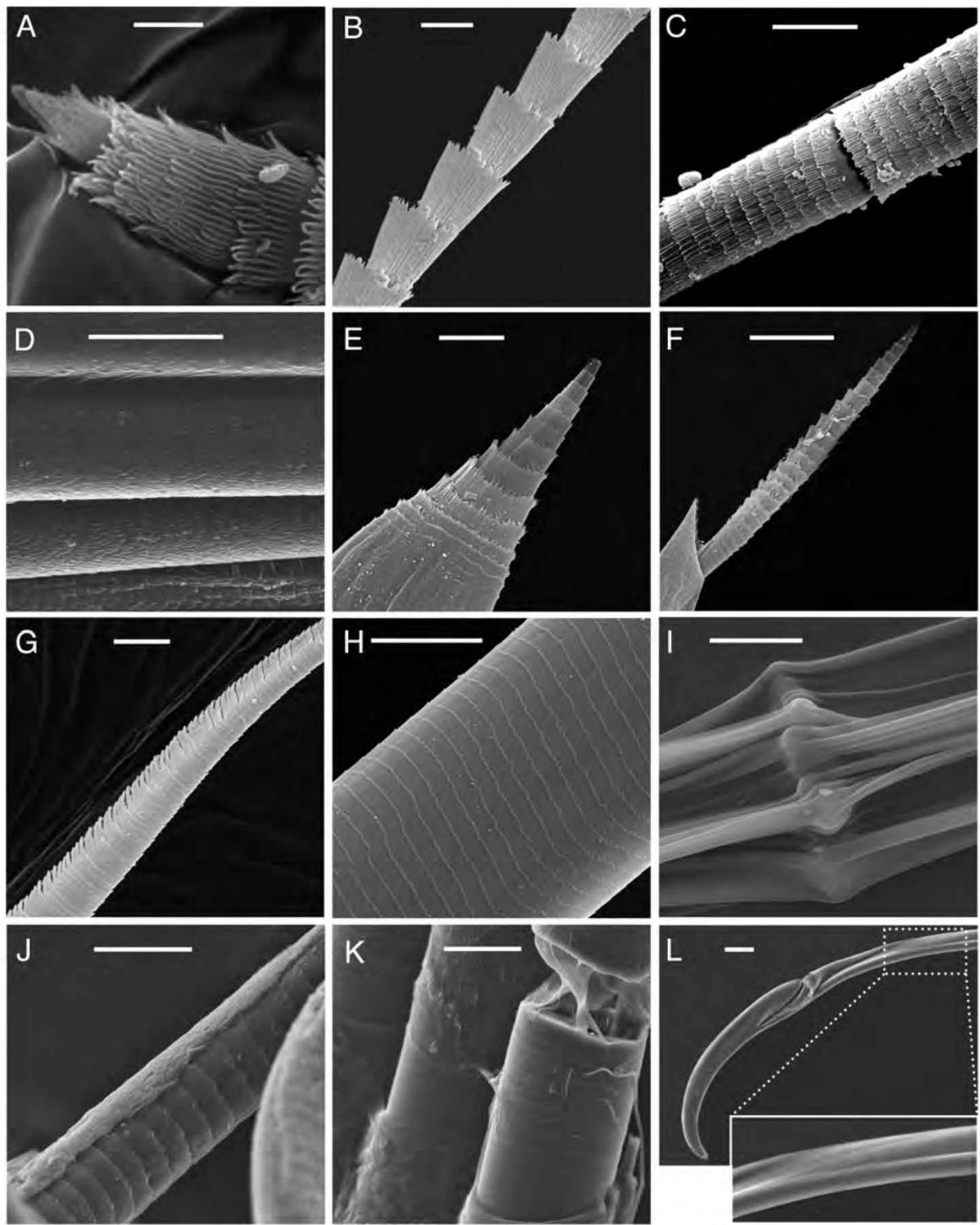

Suppl. Figure 2. Acrocirrid $(\mathrm{A}-\mathrm{H})$ and flabelligerid $(\mathrm{I}-\mathrm{L})$ chaetae. A. Shining Bomber distal tip neurochaeta. B. Juanita worm notochaeta. C. Tiburon Bomber neurochaeta. D. Acrocirrus validus notochaetae. E. Tawi-tawi Bomber notochaeta distal tip. F. Tawi-tawi Bomber distal element neurochaeta. G. Squidworm distal portion neurochaeta. H. Squidworm shaft of neurochaeta. I. Flota sp. segment joint of notochaetae. J. Pherusa plumosa CA medial portion notochaeta. K. Pherusa plumosa CA basal portion notochaetae. L. Flabelligera mundata neurochaeta. Scale bars, A $2 \mu \mathrm{m}, \mathrm{B}-\mathrm{D}, \mathrm{G}, \mathrm{I} 10 \mu \mathrm{m}$, E-F, H, J-L $40 \mu \mathrm{m}$. 
1. Branchial membrane

2. Main branchiae elliptical

3. Retractable head

4. Cephalic hood

5. Achaetous anterior segments

6. Cephalic cage (lacking in Brada and Diplocirrus)

7. Papillae

8. Subulate head branchiae

9. Chaetae not smooth

10. Prostomium dorsal, plate-like

$1,3,4,6$

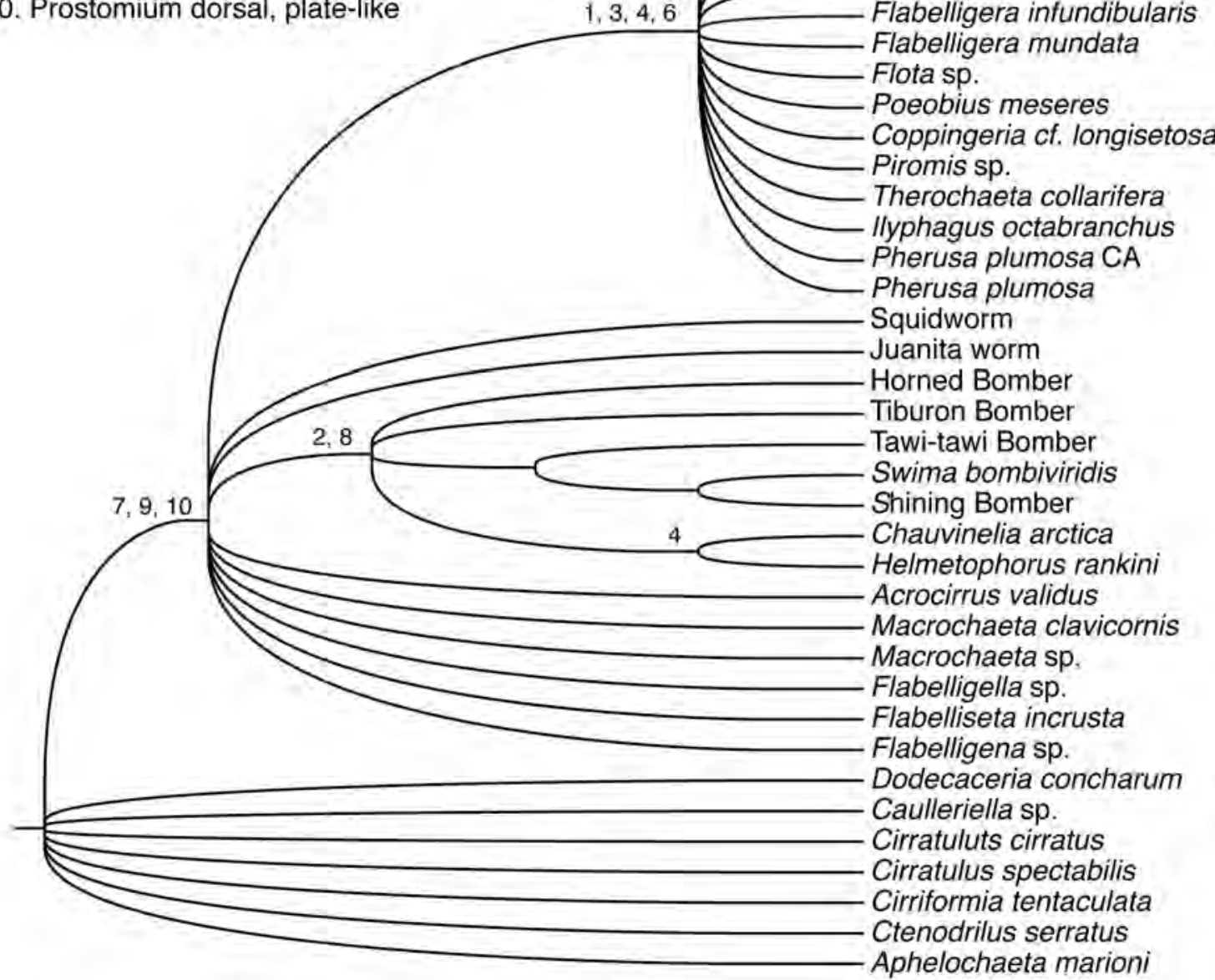

Suppl. Figure 3. Strict consensus of 1,046,189 most parsimonious trees (tree length $=$ 96) from analysis of the morphology matrix. 


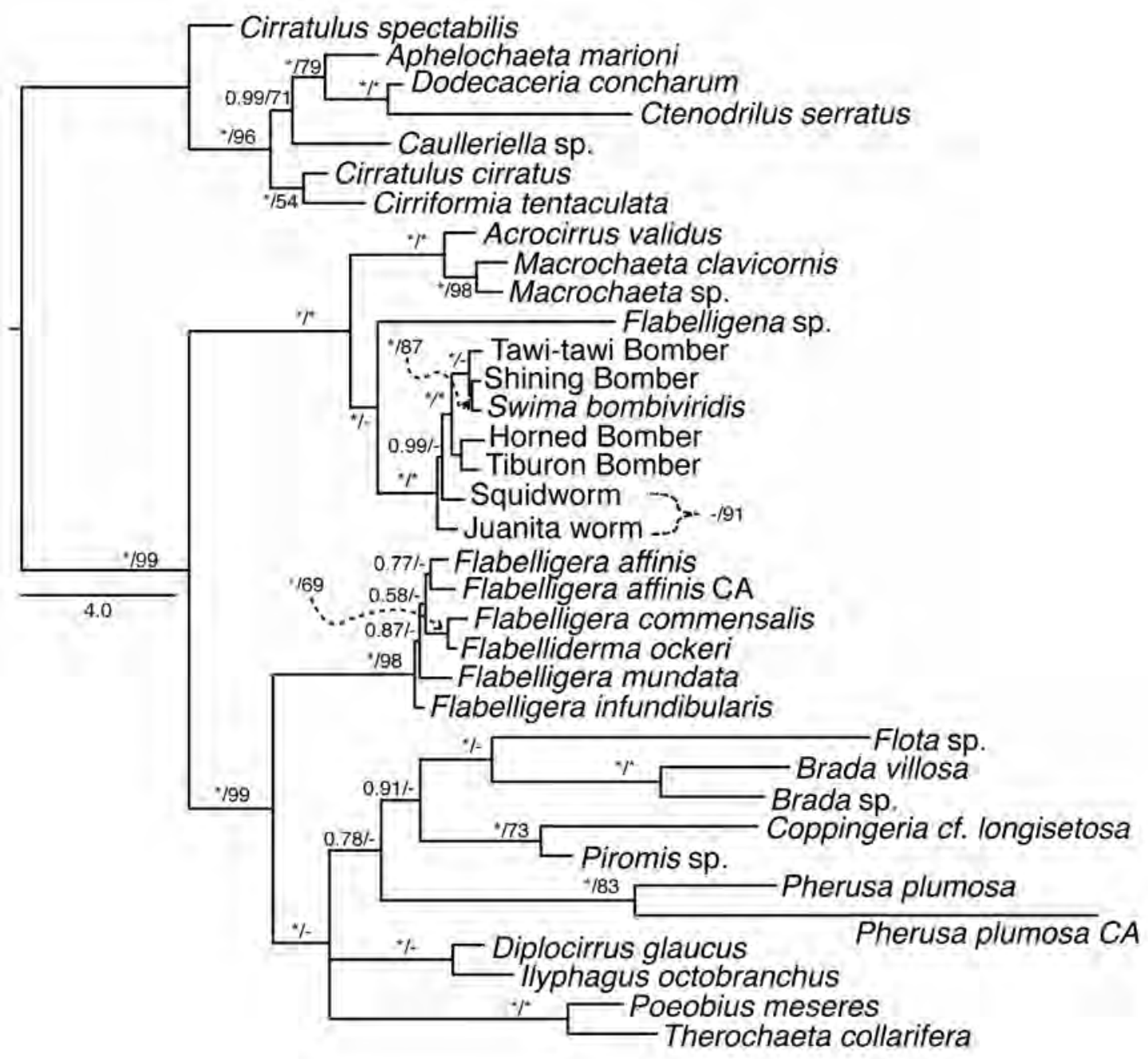

Suppl. Figure 4. Majority rule consensus tree from Bayesian analyses of five concatenated genes. Data were partitioned by each gene and first, second and third codon positions. $C y t B$ third positions were excluded due to saturation. Support is indicated as posterior probabilities from the Bayesian analyses/bootstraps from the parsimony analysis. Asterisks indicate 1.0 or $100 \%$ support respectively; dashes indicate unsupported nodes. 
Appendix I. Matrix of multistate coding scores of morphology. Unknowns are coded with “?” and inapplicable with “_“.

Character

\section{Cirratulidae}

Aphelochaeta marioni

Caulleriella sp.

Cirratulus spectabilis

Cirratulus cirratus

Cirriformia tentaculata

Ctenodrilus serratus serratus

Dodecaceria concharum

\section{Acrocirridae}

Acrocirrus validus

Chauvinelia arctica

Flabelligella sp.

Flabelligena sp.

Flabelliseta incrusta

Helmetophorus rankini

Horned Bomber

Juanita worm

Macrochaeta clavicornis

Macrochaeta sp.

Shining Bomber

Squidworm

Swima bombiviridis

Tawi-tawi Bomber

Tiburon Bomber

Flabelligeridae

Brada sp.

Brada villosa

Coppingeria sp.

Diplocirrus glaucus

$\begin{array}{lllllllllllllllllllllllllllll}1 & 2 & 3 & 4 & 5 & 6 & 7 & 8 & 9 & 10 & 11 & 12 & 13 & 14 & 15 & 16 & 17 & 18 & 19 & 20 & 21 & 22 & 23 & 24 & 25 & 26 & 27 & 28 & 29\end{array}$

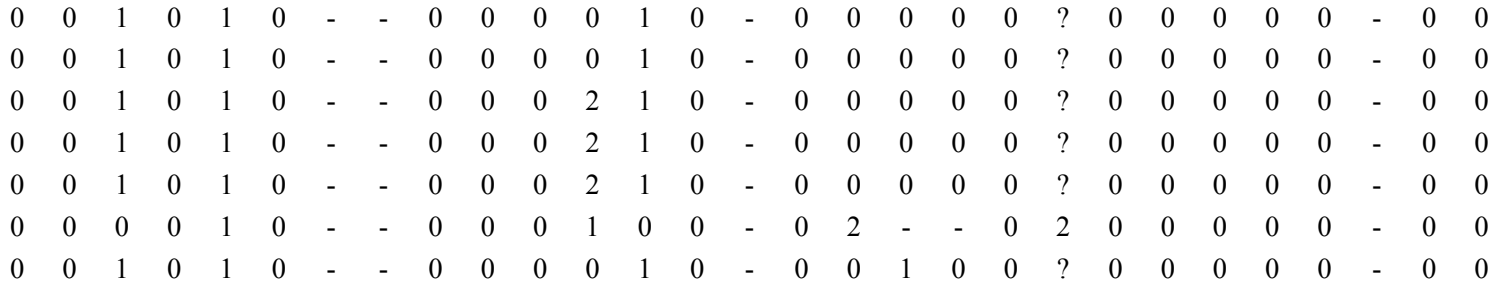




\begin{tabular}{lccccccccccccccccccccccccccccc} 
Character & $\mathbf{1}$ & $\mathbf{2}$ & $\mathbf{3}$ & $\mathbf{4}$ & $\mathbf{5}$ & $\mathbf{6}$ & $\mathbf{7}$ & $\mathbf{8}$ & $\mathbf{9}$ & $\mathbf{1 0}$ & $\mathbf{1 1}$ & $\mathbf{1 2}$ & $\mathbf{1 3}$ & $\mathbf{1 4}$ & $\mathbf{1 5}$ & $\mathbf{1 6}$ & $\mathbf{1 7}$ & $\mathbf{1 8}$ & $\mathbf{1 9}$ & $\mathbf{2 0}$ & $\mathbf{2 1}$ & $\mathbf{2 2}$ & $\mathbf{2 3}$ & $\mathbf{2 4}$ & $\mathbf{2 5}$ & $\mathbf{2 6}$ & $\mathbf{2 7}$ & $\mathbf{2 8}$ & $\mathbf{2 9}$ \\
\hline Flabelliderma ockeri & 1 & 1 & $?$ & 1 & 0 & 1 & 1 & 1 & 1 & 2 & 2 & 0 & 1 & 1 & 0 & 0 & 1 & 0 & 0 & 0 & 0 & 1 & 0 & 1 & 1 & 0 & 2 & 1 & 1 \\
Flabelligera affinis & 1 & 1 & $?$ & 1 & 0 & 1 & 1 & 1 & 0 & 2 & 2 & 0 & 1 & 1 & 0 & 0 & 1 & 0 & 0 & $?$ & 0 & 1 & 0 & 1 & 1 & 0 & 2 & 1 & 1 \\
Flabelligera affinis CA & 1 & 1 & $?$ & 1 & 0 & 1 & 1 & 1 & 0 & 2 & 2 & 0 & 1 & 1 & 0 & 0 & 1 & 0 & 0 & $?$ & 0 & 1 & 0 & 1 & 1 & 0 & 2 & 1 & 1 \\
Flabelligera commensalis & 1 & 1 & $?$ & 1 & 0 & 1 & 0 & 0 & 0 & 1 & 2 & 0 & 1 & 1 & 0 & 0 & 1 & 0 & 0 & $?$ & 0 & 1 & 0 & 1 & 1 & 0 & 2 & 1 & 1 \\
Flabelligera infundibularis & 1 & 1 & $?$ & 1 & 0 & 1 & 1 & 1 & 0 & 2 & 2 & 0 & 1 & 1 & 0 & 0 & 1 & 0 & 0 & $?$ & 0 & 1 & 0 & 1 & 1 & 0 & 2 & 1 & 1 \\
Flabelligera mundata & 1 & 1 & $?$ & 1 & 0 & 1 & 1 & 1 & 0 & 2 & 2 & 0 & $?$ & 1 & 0 & 0 & 1 & 0 & 0 & $?$ & 0 & 0 & 0 & 1 & 1 & 0 & 2 & 1 & 1 \\
Flota sp. & 1 & 1 & $?$ & 0 & 0 & 1 & 1 & 0 & 0 & 2 & 2 & 0 & 0 & 1 & 0 & 0 & 1 & 3 & 0 & 0 & $?$ & 1 & 0 & 1 & 0 & 0 & - & 1 & 1 \\
Ilyphagus octobranchus & 1 & 1 & $?$ & 1 & 1 & 1 & 1 & $?$ & 1 & 0 & $?$ & 0 & $?$ & 1 & $?$ & 0 & 1 & 0 & 0 & $?$ & 0 & 0 & 0 & 1 & 0 & 0 & - & $?$ & $?$ \\
Pherusa plumosa & 1 & 1 & $?$ & 1 & 0 & 1 & 0 & $?$ & 1 & 0 & 2 & 0 & 1 & 1 & 0 & 0 & 1 & 1 & 0 & $?$ & 0 & 0 & 0 & 1 & 0 & 0 & - & $?$ & 1 \\
Pherusa plumosa CA & 1 & 1 & $?$ & 1 & 1 & 1 & 0 & $?$ & 1 & 0 & 2 & 0 & 1 & 1 & 0 & 0 & 1 & 1 & 0 & 1 & 0 & 0 & 0 & 1 & 0 & 0 & - & $?$ & 1 \\
Piromis sp. & 1 & 1 & $?$ & 1 & 1 & 1 & 0 & $?$ & 1 & 2 & 2 & 0 & 1 & 1 & 0 & $?$ & 1 & $0 \& 1$ & 0 & $?$ & 0 & 1 & 0 & 1 & 1 & 0 & - & $?$ & 1 \\
Poeobius meseres & 1 & 1 & - & - & 1 & 1 & 1 & $?$ & 0 & 2 & 1 & 0 & 0 & 1 & 0 & 0 & 1 & 0 & 0 & 0 & 0 & 0 & - & 3 & - & - & - & 1 & 1 \\
Therochaeta collarifera & 1 & 1 & $?$ & 1 & 1 & 1 & 1 & $?$ & 1 & 0 & $?$ & 0 & $?$ & 1 & $?$ & 0 & 1 & 1 & 0 & $?$ & 0 & 0 & 0 & 1 & 1 & 0 & 2 & $?$ & $?$ \\
\hline & & & & & & & & & & & & & & & & & & & & & & & &
\end{tabular}

\section{Characters}

1. Retractable head: 0 . absent or 1. present.

2. Cephalic hood: 0. absent or 1. present.

3. Achaetous anterior segments: 0 . absent, 1. possessing 1, 2. possessing 2, 3. possessing 3, 4. possessing 4, or 5. possessing 6 .

4. Cephalic cage (chaetae of first chaetiger at least $1 / 3$ longer than those of midbody): 0 . absent or 1 . present.

5. Externally obvious segment margins on majority of body: 0. present or 1 . absent.

6. Papillae: 0 . absent or 1 . present.

7. Body papillae: 0 . short or 1. long, clavate.

8. Interramal papillae: 0 . short, 1. clavate, 2. lollipop, or 3. balloon.

9. Sediment adhered to body: 0 . absent or 1. present.

10. Gelatinous sheath: 0 . absent, 1. thin, doesn't obscure features, or 2. thick, obscures features such as parapodial rami. 
11. Prostomium shape: 0 . terminal, lobe-like, with projecting anterior margin, 1. dorsal, plate-like, posterior margin smooth, not projecting posteriorly over segments, or 2. dorsal, plate-like, posterior margin projecting posteriorly over segments.

12. Grooved palps: 0.1 pair, 1 . absent, or 2 . more than one pair.

13. Eyes: 0. absent or 1. present.

14. Nuchal organs: 0 . pit only, 1. ciliate ridge only, 2. at least part of ciliated ridge on a free-standing oppositely branched structure, or 3. at least part of ciliated ridge on free-standing, oppositely branched and spiral structures.

15. Nuchal organs (ridge shape): 0. straight (with less than 180 degree bend), 1. U-shaped (with single 180 degree bend), 2. convoluted (with multiple 180 degrees bends).

16. Head branchiae: 0 . absent or 1 . subulate, not easily lost.

17. Main branchiae: 0 . on one or more segments, not on branchial membrane, 1 . on branchial membrane, or 2 . absent.

18. Main branchiae (number pairs): 0. more than 4 pairs, 1.4 pairs, 2.3 pairs, 3.2 pairs

19. Main branchiae (shape): 0. long, tapered or 1. short, elliptical.

20. Nephridiopores as papillae: 0 . absent or 1 . present.

21. Nephridiopores (location): 0. branchial membrane, 1. segmental, or 2. peristomial.

22. Parapodia distinct from body wall: 0 . absent or 1 . present.

23. Anterior chaetigers (one or more): 0. biramous or 1. uniramous.

24. Chaetae: 0. smooth, 1. cross-barred, segmented, 2. spinous, or 3. absent.

25. Compound chaetae: 0 . absent or 1 present.

26. Broad, flattened chaetae: 0. absent, or 1. present.

27. Neurochaetae (second element): 0. straight, 1. curved, or 2. hooked.

28. Discrete gonads in few segments: 0. absent or 1. present.

29. Gut: 0. straight or 1. looped 